\title{
Visuaalse rahvaluule kollektsionäär Kaljo Põllu
}

\author{
Riin Kübarsepp
}

\begin{abstract}
Teesid
Kaljo Põllu (sünd 1934) tuli eesti kunsti ja kunstiellu 1962. aastal, mil ta asus äsjadiplomeeritud klaasikunstnikuna tööle Tartu ülikooli kunstikabineti juhataja ametisse. Algul oli ta Tartu pallaslikus kunstielus kui nn Tallinna saadik, kes tõi ülikoolilinna avangardismihõngu ning viljeles op-, pop- jm moodsat kunsti. 1967. aastal loodi tema algatusel kunstirühmitus Visarid. Kui üheks ülikooli interdistsiplinaarseks mõttekeskuseks kujunenud kunstikabinet 1973. aastal peahoone lähedusest Tiigi tänavasse viidi ja oma tähtsuse vaimse liidrina koatas, lahkus K. Põllu Tallinna, kus muutus ka tema kunstnikukäekiri. Juba ülikoolilinnas olid tekkinud sidemed fennougristidega ja K. Põllu oli käinud õppereisidel sugulasrahvaste juures. Kunstniku Tallinna-perioodil sai soome-ugri ürgalge tema teoste põhisisuks. Graafikasarjade "Kodalased", "Kalivägi", "Eesti maastikud" ning "Maa ja taevas" omanäolisus on teinud Kaljo Põllust suure kunstniku mitte üksnes Eesti kontekstis, vaid (vähemasti) kogu põhjamaises kunstimaailmas.
\end{abstract}

Märksõnad: avangardism, graafika, kaljujoonised, metsotinto, soomeugrilisus, Visarid, Tartu ülikooli kunstikabinet

"Igaüks tahab aru saada kunstist," kirjutas Picasso, "miks mitte proovida aru saada linnulaulust?... Inimesed, kes pü̈̈avad pilte seletada, on enamasti valel teel"(Wittgenstein 1996).

\section{Eemaldumine sotsialistliku realismi kaanonist}

1962. aastal lõpetas Kaljo Põllu (sünd 1934) Eesti Riikliku Kunstiinstituudi klaasehistöö erialal ja asus tööle Tartu ülikooli kunstikabineti juhatajana.

Jaak Kangilaski väitel olid 1960. aastad aeg, mil Eesti kunstnikkond tegi läbi arengu, kus oma loomingus jõuti ždanovlusest Herbert Readini. J. Kangilaski peab üheks nullpunktiks, millega tuleks hilisemaid kunstiteoseid võrrelda, nõukogude kunstiloo süngeimat perioodi, 1950. aastaid. See oli loomingu jm vabaduste tuge- 


\section{Riin Kübarsepp}

vaima allasurumise aeg. Eemaldumine sellisest kunsti nulltasandist algas kohe, kui ilmnesid esimesed poliitilise sula märgid (Kangilaski 1997: 3).

Aasta 1955 on oluline daatum mitte üksi kujutavale kunstile, vaid sisuliselt tähistas see teatud liberaliseerimistendentsi kultuuri ideoloogilises juhtimises. Eesti kunstile oli oluliselt tähtis, et taas hakkas lubatavaks muutuma kunsti esteetilise olemuse paradigma. Esteetilise sfääri autonoomia tekkimist võib vaadelda osana moderniseerumisest, mis käivitus NSV Liidus 1950. aastate teisel poolel. Seda iseloomustas eelkõige "ratsionaalse argumenteerimise" võimalikuks muutumine kujutavas kunstis. Tsiteerides Sirje Helmet:

[---] ei tekitanud 1955. aasta otsus uut paradigmat eesti kunstimentaliteeti, kuid andis võimaluse traditsioonilisel paradigmal võtta enda kanda mitu rolli - olla nii uuendusliku kunsti kui vaikse opositsiooni aluseks (Helme 2000: 259).

Lähimaks eesmärgiks enamikule kunstnikele oli kunsti autonoomia, kus kunstnikul on õigus ka isiklikule käekirjale. Kunstivormide mitmekesisus ja uuenemine oli sellises situatsioonis vältimatu. Eemaldumine sotsialistliku realismi kaanonist ja poliitilisest propagandast oli esialgu ettevaatlik ja aeglane. Ometi võis antud konteksti iga väike vormiuuendus paista silma ja koguni omandada poliitilise tähenduse.

Kuigi uuendused olid vastuolus kunstiliselt ja poliitiliselt konservatiivsemate jõududega, oleks liiga lihtsustav kujutada Eesti NSV kunstielu vastuoluna skaalal, kus ühe otsa moodustab võim (ametlik kunst), teise aga liikumine rahvusvahelise avangardi poole. Siinkohal võib nõustuda J. Kangilaski klassifikatsiooniga, kus tunnistatakse hoopis kolme kultuuripoliitilise jõu ja diskursuse olemasolu. Need olid okupatsioonivõimu, avangardiorienteerumise ja rahvuslik-konservatiivsete jõudude kunstipoliitilised diskursused (Kangilaski 1997: 5).

Rahvuslik-konservatiivne kunstipoliitiline diskursus hindas kõrgelt sotsialistlikust realismist eemaldumist, kuid kunsti uuenemine oli väärtuslik ainult niivõrd, kuivõrd see teenis eestlaste identsuse säilitamist.

Lisaks kujunes 1960. aastate keskpaigaks välja omaette nähtus: eesti kunsti kaitsemehhanism. Kaitsemehhanismile iseloomulikud tunnused kunstis avaldusid eesti kunstile omases koloriidi- 


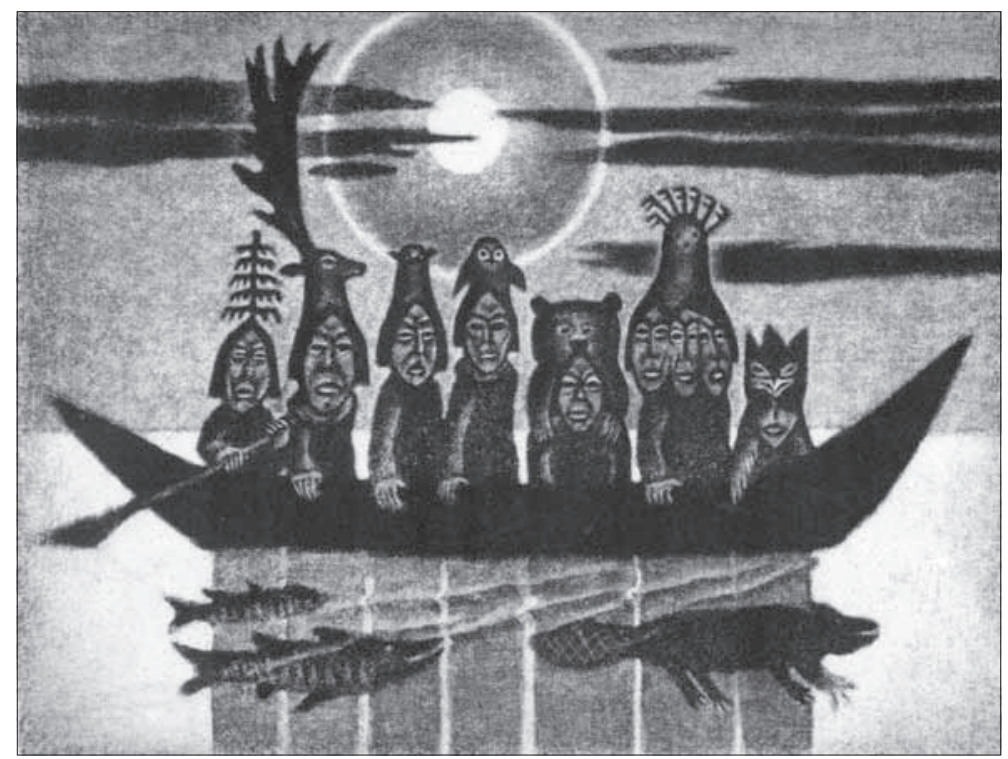

Joonis 1. Kaljo Põllu "Päikesevene" (sarjast "Kodalased”). Metsotinto $37 \times 49 \mathrm{~cm} .1974$.

meeles, vormitajus, diskreetsuses ja selges vormis. Peaeesmärk oli erineda sotsialistlikust realismist. Tulemuseks oli esialgu literatuursusele kalduv, hiljem aga rõhutatult paatoslik ja romantiline vorm. Samas sisaldas see eestlaste privaatsussoovi ja vaimset separatismi, mis viis kunstis isolatsiooni ja eraldumiseni konkreetse ühiskonna reaalsusest. Sellist varjatud omapoolse ideoloogilise kasuga eraldusjoont tunnustas ka üleliiduline kunstimasinamehhanism. Kujunes olukord, kus eesti kunst erines suurest osast Nõukogude impeeriumi kunstist. 1960. aastate arengus oli sellel vaimsel kaitsevallil oluline positiivne roll. S. Helme sõnul kujuneski 1950. aastate lõpu ja 1960. aastate ideaalide alusel välja nn eesti kunsti pealiin. Sealjuures viis rühmitus ANK '64 1960. aastate lõpul paljud kunstiotsingud radikaalse äärmuseni, tuues eesti kunsti teadliku eemalehoidmise, enesesse kapseldumise ja jaheda privaatsuse.

Avangardismile orienteeritud diskursus oli poolavalik, kuid mõjutas olulist osa kunstnikest ja ärksamast publikust. Rahvusvahelise avangardi ideoloogia oli teatavasti individualistlik, kosmopo- 


\section{Riin Kübarsepp}

liitne ja elitaarne. Rahvuslik-konservatiivse diskursuse seisukohalt olid avangardimeelsed ühelt poolt sümpaatsed ja imetlusväärsed, kuid teisalt kahtlased või koguni ohtlikud (selles osas, mis õonestas kunsti kuulumist rahvale ja rõhutas rahvuslikku identiteeti).

Ometi olid okupatsioonimeelsete ja rahvuslik-konservatiivse kunstipoliitika strateegilised eesmärgid vastandlikud, sest esimeste eesmärk oli hävitada, viimastel aga säilitada rahvuslikku identiteeti (Kangilaski 2001: 224).

Sellise klassifikatsiooni alusel kuuluks Kaljo Põllu oma Visarite-aegse loominguga avangardismimeelsete, soome-ugriliku maailmavaate poolest aga rahvuslik-konservatiivsesse diskursusesse. Ometi oleks tema liigitamine rahvuslikuks konservatiiviks ekslik, sest tegemist on kunstnikutüübiga, kes on oma soome-ugriliku temaatikaga sõltumatu nii poliitikast kui ka ideoloogiatest.

1960. aastate jooksul avangardismimeelne ja rahvuslik-konservatiivne kunstidiskursus lähenevad teineteisele ja alustavad koostööd. Kriis nende suhetes tekkis 1960. aastate lõpul ja 1970. aastate algul, kui Eestisse hakkas jõudma rahvusvahelise avangardi paradigmamuutuse mõju.

J. Kangilaski väitel olid uusvasakpoolsed ühelt poolt küll aktiivselt ja sõjakalt võimu, teisalt kodanlike eluväärtuste ja rahvusluse vastu. Anarhistlikku tüüpi kontrakultuur oli ainuke avalik opositsioon ja võimudele kahtlemata ebamugav, kuid samal ajal kasulik, sest see lõhkus publiku ja kunsti sidet, desintegreeris kultuuri ja andis võimudele kui normaalse elukorra kaitsjatele legitiimsuse. Kunsti radikaliseerumine lääne avangardi uue paradigma vaimus oli raskesti omaksvõetav, sest vasakpoolsus (mis Eestis oli formaalse ja naeruväärsena välistatud, aga nüüd Läänes tõsimeelsena sisse tungis) oli enamikule vastumeelne.

Mitmed eesti kunstnikud hakkasid kasutama lääne neoavangardi mässulisi ja antiesteetilisi teoseid formaalselt, püüdes neid estetiseerida või tõlgendada ainult vormiuuendusena. Üks osa eesti kunstnikest pettus lääne avangardi arengus ja tõmbus endasse. Jätkati kord loodud vormisüsteemi viimistlemist või siirduti ideoloogilistel põhjustel avangardist täiesti sõltumatutele radadele. Viimase variandi valinute hulgast võibki parimate näidetena tuua 1960. aastate radikaalsemad uuendajad Olav Marani ja Kaljo Põllu (Kangilaski 1997: 7).

Samalaadne raske valik oli eesti kunstnike ette seatud ka suhtumises Moskva põrandaalusesse seltskonda. Viimase võimuvasta- 
sus ja rahvusvaheline maine tegi ta eesti kunstnike loomulikuks liitlaseks. Tuleb aga arvestada, et ka nende kunstnikega koostööst hoidumine polnud ainult oma naha hoidmine, vaid tihti olid sellel arvestatavad ideoloogilised põhjused.

Mõnikord olid Moskva põrandaalustega suhete vältimise põhjuseks isiklikud konfliktid või huvipuudus ja isegi nende tegevuse alahindamine. Ka K. Põllu distantseerus Moskva kunstnike Eesti sõpruskonnast sihilikult ja püüdis leida oma, eriilmelist kunstiväljundit. Tolleaegsed nn kultuuriaktivistid valisid karjerismi, dissidentluse või kultuurilise eneseteostuse tee. Tekkis omamoodi uus esteetika, mida ei tunnistanud omaks ei nõukogulik ega rahvuslikule traditsioonile apelleeriv hoiak. Traditsioonidega seotud rahvusliku identiteedi kinnistuse järele tekkis suurem vajadus (Epner \& Annus \& Järv et al. 2001: 421).

\section{Visarite aegu}

1964. aastal algab kunstirühmituste periood - ANK '64, veidi hiljem Visarid ja SOUP 69. Varem lihtsalt ei olnud võimalik end sarnaste tõekspidamiste, karmi stiili vastase ja radikaalsete vaadetega rühmitusena manifesteerida, sest siis oleks seda tõlgendatud vaenulikkusena nõukogude korra suhtes.

Revolutsiooniline, nn mässajate maine kuulub 1960. aastate kunstirühmitustele, kes vastandasid end nii ametlikule kunstile kui ka eesti kunsti varasematele traditsioonidele, eriti just 1930. aastail Pallase koolkonda iseloomustanud järelimpressionismi lainele, mis oli siiani olnud uuendajatele nii tabuks kui ka imetlusobjektiks (Talvistu 1997: 9).

Oma kunstipüüdlused deklareeris 1967. aastal loodud kunstirühmitus Visarid ka käsikirjalises manifestis, kus esitati oma kreedo:

Kunstnikust saab homse päeva automatiseeritud ja vabaaja ühiskonna asendamatu sisustaja. Lõputute seeriate kunsti, nagu eri kunstiliikide sünteesi olemasolugi puhul, pole enam tegemist elukeskkonna lihtsa muutmisega, vaid selle keskkonna psü̈̈hilisaistingulise ulatuse ning inimese tähelepanu- ja fantaasiavõime muutmisega. Eesmärgiks saab totaalne kunst, kunst kõikjale, kunst kõigile (Põllu 1971: 3). 


\section{Riin Kübarsepp}

Selle ajajärgu paradoksiks võib pidada asjaolu, et kuigi räägiti palju uuendustest, oli selle taga sageli tugev seos 1920. ja 1930. aastate traditsioonidega. Tagasipöördumine millegi vana juurde oli kahtlemata uuendus võrreldes sotsialistliku realismi kaanoniga, kuid laiemas plaanis oli ikkagi tegu tagasipöördumisega millegi olnu juurde. Kirjandusteadlase Luule Epneri väitel olid sellised naasmised paralleelsed erinevatel aladel, näiteks pole raske rööbitada arbujalikkuse rehabiliteerimist kirjanduses pallaslikkuse juurde naasmisega kunstiloomingus. Modernistlikust kirjanduskogemusest laenati üksikuid vormivõtteid, orienteerudes esialgu üksikute progressiivsete modernistide loomingule. Ilmnesid mit-

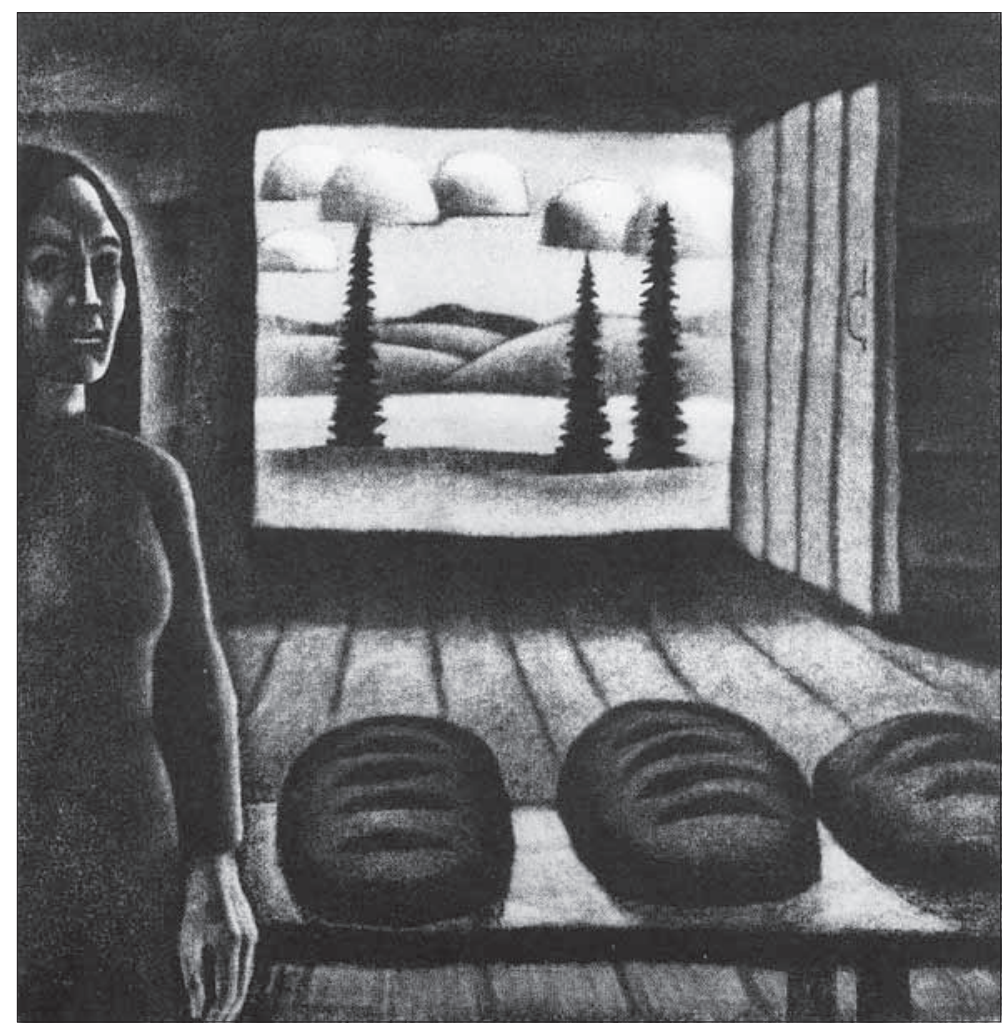

Joonis 2. Kaljo Pôllu "Leib" (sarjast "Kodalased"). Metsotinto. $37 \times 36 \mathrm{~cm} .1974$. 
med koha- ja ajastuomased erijooned. Seega kujundas üldist tonaalsust sageli uute maailmade avastamine ja uue elu romantika, käsikäes tunnetusliku optimismi ja esimeste kosmoselendudega, mis tekitas kosmilise haardega antropotsentristlikud kujundid (Epner \& Annus \& Järv et al. 2001: 417).

Siseemigratsioonis viibinud Uku Masingu ja Artur Alliksaare ümber kogunesid noorte austajate seltskonnad, tekitades nõnda mitteformaalse kultuurielu. Kirjanduses tekitas järjekordse murrangu esimeste luulekassettide ilmumine 1962. aastal - "Noored autorid 1962" (Raul-Eerik Rummo, Linda Ruud, Arvi Siig, Mats Traat, Enn Vetemaa). 1960. aastate algul kujunesid Tartu ülikooli kunstikabineti seltskonnal head suhted ka Tallinna Noorte Autorite Koondise (NAK) almanahhi "Hees" autorkonnaga.

Kõige üldisemalt tähendas see nii kirjanduses kui ka kunstis kitsas mõttes sotsialistliku realismi paradigma valitsusaja lõppu. Tõlgenduslikult aitas sellele kaasa prantsuse marksisti Roger Garaudy käsitlus piirideta realismist, mis vabas tõlgenduses lubas realismi alla paigutada mis tahes esteetikat. Kuigi ka R. Garaudy sattus 1960. aastate lõpul nõukogude võimuga vastuollu, olid selleks ajaks kätte õpitud mõttekäigud, mis aitasid kaitsta kirjanike ja kunstnike esteetilisi vabadusi (Epner \& Annus \& Järv et al. 2001: 418).

1960. aastate lõpul ja 1970. aastate alguses snihkuvad esiplaanile modernistlikud tendentsid nii kunstis kui ka kirjanduses. Samas nendivad mõned käsitlused juba 1960. aastatel mitmete postmodernistlike joonte teket. Sellised üldistused viitavad tollaste protsesside mitmepalgelisusele.

\section{Hüpe kirjanduse kaudu modernismi suunas}

Siinkohal vaatleme Kaljo Põllu loomingu kujunemist paralleelselt 1960. aastate lõpu ja 1970. aastate alguse sündmustega eesti kirjanduselu taustal.

Kirjandusteadlase Tiit Hennoste väitel leidis eesti kirjanduses ja ka teistel klassikalistel kultuurialadel 1960. ja 1970. aastate vahetusel, peamiselt alates 1960. aastate teisest poolest aset hüpe modernismi suunas. Tartu noored teatritegijad pöördusid Jerzy Grotowski, Antonin Artaud' jt Euroopa modernismiklassikute poole. Olulisemad nimed on siinkohal Evald Hermaküla, Jaan Tooming, 


\section{Riin Kübarsepp}

Mati Unt ja Paul-Eerik Rummo. Kirjanduses tähendas see üksikute modernismivõtete imbumist tekstidesse, esimesena võib välja tuua sisemonoloogi kasutamist (Hennoste 1996a: 69).

Tekstiehituse alal laenab eesti modernism valdavalt normaalmodernismi klassikalisi võtteid nende lahjendatud kujul. Siin on tähtsaim liikumine välisilmast inimese siseilma ja sellega seotud muutused tekstis: narratiivsuse vähenemine ja sisekõne võtete rohkenemine (Hennoste 1996b: 91).

Visuaalne sisemonoloog kajastus samas üsna selgelt ka Kaljo Põllu tolleaegsetes töödes, kus tema üksikud graafilised lehed peegeldasid vaikust ja suletust, olles sealjuures ka ennastanalüüsivad.

T. Hennoste väitel kujunes 1960. aastatel välja kõrgkultuurist kõrvale jääv underground- ja rock-kultuuri tekstimaailm, kus elasid släng, argikeel, luuletus kui poliitiline seisukohavõtt, luuletus kui laul, riim ja rütm (Hennoste 1996a: 76). See väljendus selgelt ka K. Põllu Visarite-aegsetes töödes, kus määrava tähtsusega on literatuursed väljendid ja lauselõigud, mis sekundeerivad visuaalsele pildikeelele. Seega avaldub Johannes Saare väitel K. Põllu 1960. aastate lõppu jäävate tööde puhul popkultuuri suur tõde, et kultuur on meid totaalselt ümbritsev tasapinnaline pildiekraan (Saar 1998: 173).

Kaljo Põllu pildiruumi illusoorsuse uuringud viivad ta ajuti väga lähedale Roy Lichtensteini koomiksistiilile ("Kaks mõtet", 1967; "Tervitus", 1972). Kirgaste ja puhaste värvide, kalgilt konstrueeritud värvilaikude ja lapidaarse lihtsusega visandatud figuuride juurest puudub vaid $R$. Lichtensteini ajaleheraster.

1960. aastate lõppu iseloomustab nii kunstis kui ka kirjanduses üleüldine nõukogude süsteemi, eelkõige totalitarismi kriitika. Eesti modernismis leidub linnaihalust ja veidi kosmopolitismi, kuid samas ka möödunud sajandi ideaalide igatsust: eesti modernistlikule kirjandusele ja kunstile on rahvas ja rahvuslus palju olulisemad kui tema Euroopa suunakaaslastele.

Sünkretiseerumistendentsis on teatav väljakutse kirjanduse iseseisvusele, kuid erinevalt 1960. aastate Läänest ei tähenda see siiski sõnakunsti osa kahanemist üldises kultuurikäibes: lugemine jäi ju ikkagi põhiliseks kontaktivormiks lääne kultuuris toimuvaga - vaimuhoiakuid erinevates kultuurivaldkondades mõjutasid tugevalt teoreetilised tekstid ja ilukirjandus. Rohkem tekkis võimalusi võõrkeelse kirjasõnaga tutvumiseks ja aktiivse tõlkimise periood kestis 1970. aastate alguseni. Eestis ja mujal maailmas aktuaalsed märk- 


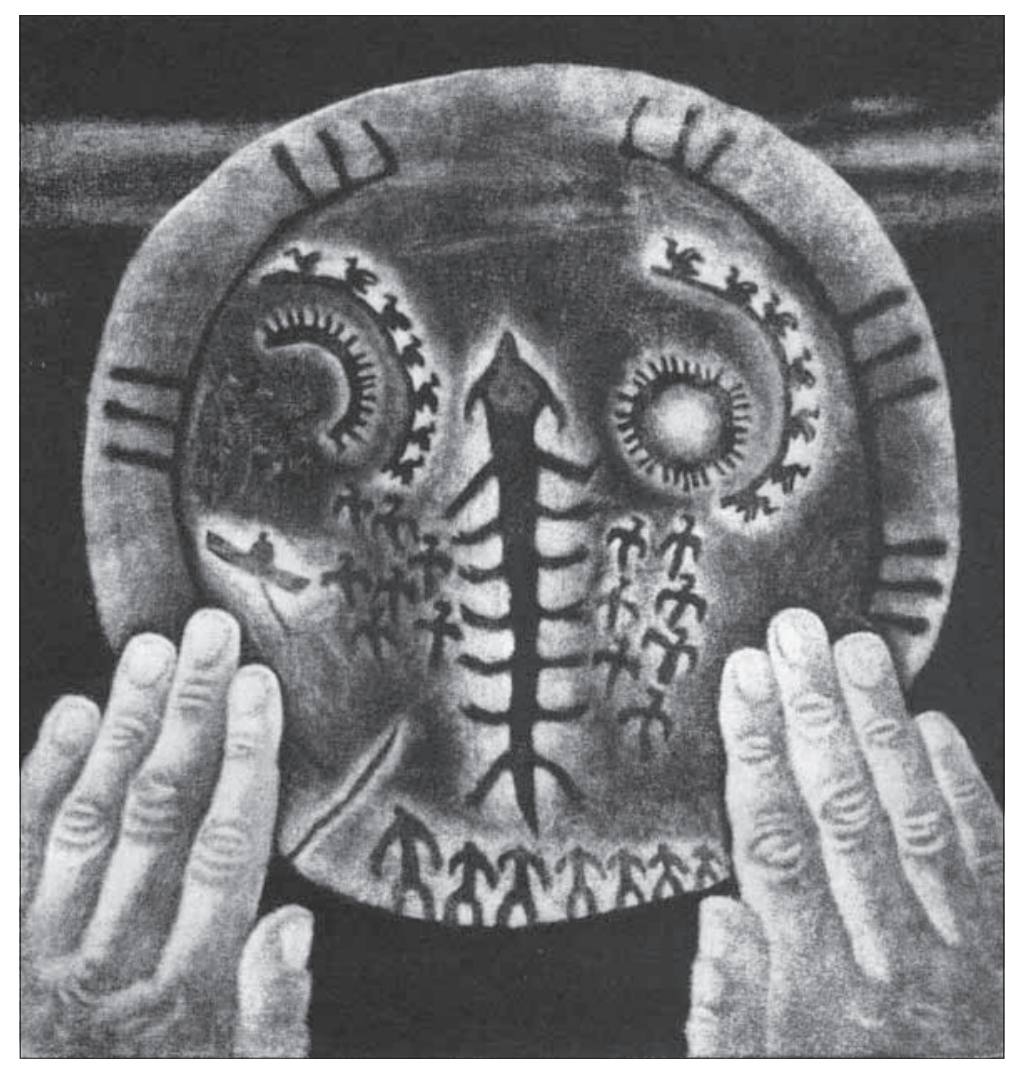

Joonis 3. Kaljo Põllu "Maailm nagu pada" (sarjast "Kodalased"). Metsotinto. $41 \times 39 \mathrm{~cm} .1974$.

sõnad ja ideoloogiad kattusid vaid osaliselt, ühine oli revolutsioonilistele muutustele orienteeritud vaimsus (Epner \& Annus \& Järv et al. 2001: 423).

1960. aastate lõpul sai L. Epneri väitel rääkida ka eesti kirjanduse sünkroniseerumisest iseendaga, sest vähenes lõhe käsikirjalise ja trükitud kirjanduse vahel: tekkis tähelepanuväärne käsikirjaliste almanahhide laine, mille kõrgaeg langes ajavahemikku 19671973.

Hüpe trükitud kirjanduses algas 1samal ajal, proosas kujunesid märksõnadeks Mati Undi ja Arvo Valtoni teosed. Tõeline murre eesti luules toimus aga aastatel 1967-1975. Esiteks oli see hüpe 


\section{Riin Kübarsepp}

modernismi poole, teiseks aga ka midagi hoopis muud, mida T. Hennoste tõlgendab hüppena üle modernismi postmodernismi poole (Hennoste 1996a: 70). Hüppena postmodernismi võib mõista ka K. Põllu pöördumist soome-ugri temaatikasse 1970. aastate alguses.
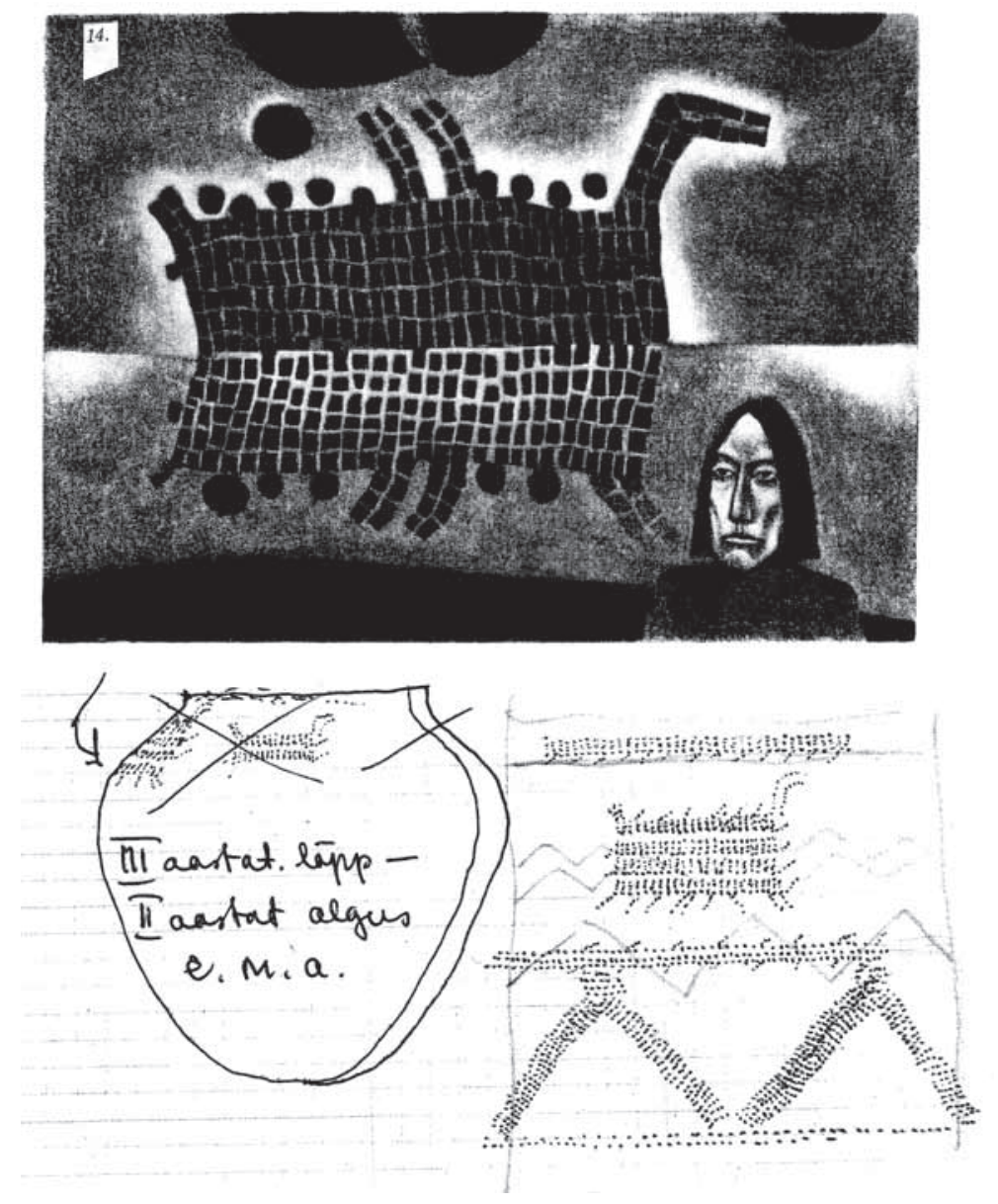

Joonis 4. Kaljo Põllu "Legend" (sarjast "Kodalased"). Metstinto $36 \times 49$ cm. 1975. Pildi all selle loomisel vidandatud detailid. Pliiats. 
Klassikalist modernismi vahendavad eesti luules A. Alliksaare keelemängud, P.-E. Rummo "Saatja aadressi" jahe minimalism, Andres Ehini sürrealismi. Oluliseks mõjutajateks tuleb pidada ka tollast Euroopa marksismi, milles ühendati freudism ja marksism ning mis oli tuntud vähemalt Tartus (Hennoste 1996b: 90).

1960. aastate olulisim luuletaja oli kahtlemata Paul-Eerik Rummo ja seda mitte niivõrd uuendaja, kuivõrd rahvusluuletajana. Tema 1964. aasta luulekogus "Tule ikka mu rõõmu juurde" hakkas autori mõni aasta varasem kirjanduslik elurõõm asenduma pessimismi, resignatsiooni, ohutunde ja kurbusega. Olulisteks mõjuallikateks pidas P.-E. Rummo aga tolleaegset Tartu kirjanduselu oma toa mütoloogia, kohvikute ja seltsieluga, kus põhiautoriteetideks kujunesid Artur Alliksaar ja Ain Kaalep (Hennoste 1996a: 72). Teksti ja maailma suhetes tulevad juba 1960. aastate lõpul, aga eriti intensiivselt 1970. aastatest alates esile Siberi ja Põhja-Aasia kujutelmad, budism, nägemused, liikumine une ning reaalsuse piiril (Hennoste 1996b: 88).

Kaljo Põllu soome-ugrilikus perioodis sisaldub Paul-Eerik Rummo luulega sarnane areng ja elutunnetus, mis oli ka paratamatu, sest Tartus suhtlesid kirjanikud ja kunstnikud tihedalt ning vahetult, mistõttu kirjanduses ja kunstis levis ühtne maailmavaade .

Klassikalise modernismi väljakujunenud kaanonid ühendusid 1960. aastate maailmas kontrakultuuri muutuste ja mõjudega.

L. Epneri väitel kujunes 1970. aastate alguseks nii kunstis kui ka kirjanduses laialdaselt välja "ridadevaheline" poeetika, kus tabuteemasid sõnastati nii, et need tsensuurist läbi pääseksid; analoogilist tendentsi võis täheldada ka kunstis, kus sama anti edasi visuaalsete vahenditega (Epner \& Annus \& Järv et al. 2001: 425). Sealjuures polnud kõnealune kümnendivahetus mitte ainult avangardsete püüdluste kontsentreerumise hetk, vaid ka aeg, mil elustusid mõjukad traditsioonilised hoovused kunstis (realistlik ajalooline maal), sh loodussõbralik, arhailiste algjuurte juurde pöörduv mõtteviis, mida esindab Kaljo Põllu looming.

\section{Kaljo Põllu "Tallinna saadikuna" Tartus}

Visarite ajalugu on tolleaegse Tartu Riikliku Ülikooli (TRÜ) kunstikabineti ja sealse aktiivsuse ajalugu. 1957. aastal loodi ülikooli pedagoogikakateedri juurde kunstikabinet, mille esimene juhataja 


\section{Riin Kübarsepp}

oli maalikunstnik Juhan Püttsepp, 1962. aastast töötas sellel ametikohal Kaljo Põllu, kes lahkus sealt 1975. aastal. K. Põllu saavutas, et ülikooli interdistsiplinaarne maailm koondus kunstikabinetti ning tõi sinna oma energia ja noore intelligentsi. Tartu ülikooli kunstikabinetti tööle asudes tellis K. Põllu oma esimesest palgast kõik saadavad välismaised kunstiajakirjad - Tšehhi, Poola, Ungari, Rumeenia, Vietnami ja Hiina omad. Just nende ajakirjade kaudu hakkas tulema infot nii abstraktsest kunstist, opist, popist, happeningist, assamblaažist, kollaažist kui ka ready-made'ist.

Selline väike struktuur, kus ametlikult töötas vaid üks õppejõud, kujunes omamoodi 1960. aastate lõpu ja 1970. aastate alguse kultuurifenomeniks, mis ületas piirid mitte ainult Tartu ja Tallinna konservatiivsuse ja uuendusmeelsuse vahel, vaid suhtles ka vabalt ajas nähtustega, mida peeti individuaalset ja lokaalset arengut silmas pidades vajalikuks (Helme 1997: 5).

Aastatel 1967-1972 kunstikabineti juures tegutsenud kunstnikerühmitus Visarid vahendas kohalikku kunstiellu jooksvat kirjandust Läänest, tõlkis ja propageeris selles leiduvaid ideid rühmituse tõlke-

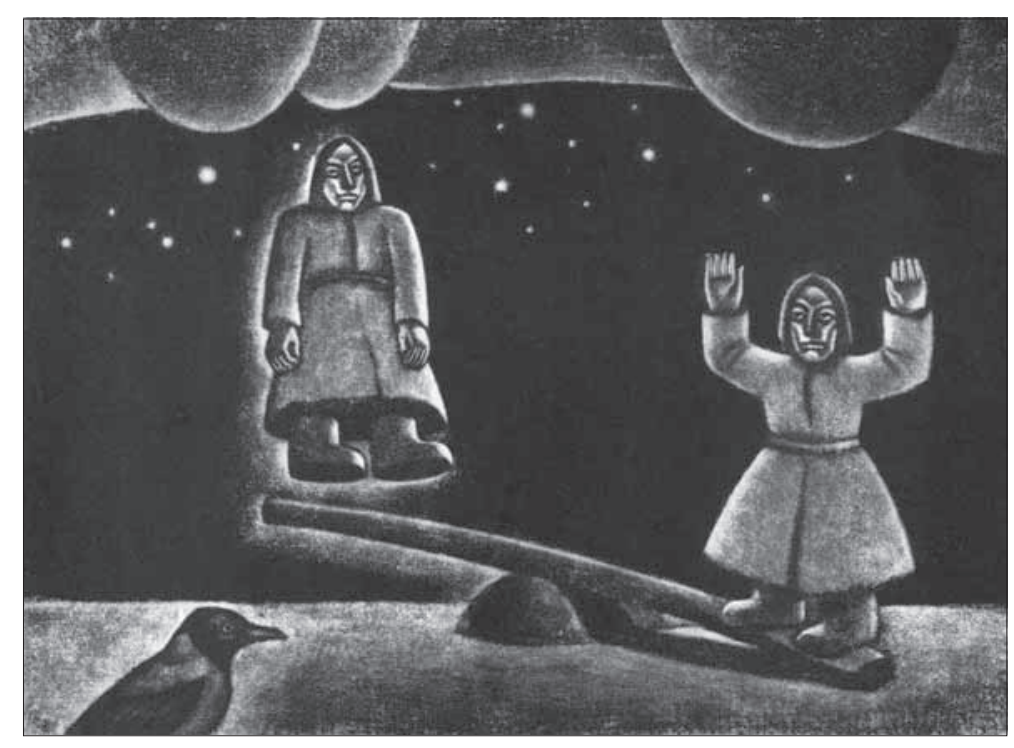

Joonis 5. Kaljo Põllu "Kahekesi" (sarjast "Kodalased"). Metsotinto. $35,5 \times 49 \mathrm{~cm} .1973$. 
kogumikes ja viljeles ka ise vastavaid kunstisuundumusi. Samasse ajavahemikku jäävad ka seitse Visarite ühisnäitust. Kaljo Põllu tollal sündinud taiesed kuuluvad 1960. aastate eesti popkunsti kullafondi, hõlmates peaaegu kõiki keskseid suundusmusi tollases eesti uuenduslikus kunstis, kujunedes seega omamoodi majakateks hetke kunstisituatsioonis orienteerumiseks (Saar 1998: 17).

Ekslikult võiks küll oletada, et Kaljo Põllu olulisteks mõjutajateks olid lisaks uutele kunstisuundadele ja lääne eeskujudele ka mitmed Tartu kunstnikud (Lembit Saarts, Kaja Kärner, Valve Janov, Silvia Jõgever, Lüüdia Vallimäe-Mark). Samas omistati Kaljo Põllule Tartus nn Tallinna saadiku maine, sest ta ei läinud kaasa sealse järelpallaslaste (Tartu Kunstnike Liidu) seltskonnaga. Kuigi sõjaeelne modernism ja Pallas olid Tartu kunstnikkonnale novaatorlikud, pidas tollaegse TRÜ kunstikabineti seltskond seda "väga hilinenud Euroopaks". Tallinna noorte ja aktiivsete kunstnike hulgas oli valdav suhtlemine Moskva ja Leningradi avangardiga. K. Põllu hoidus aga sellistest kontaktidest, usaldades otse Läänest Tartusse jõudvat teavet (Põllu 1971: 3). Osundagem Kaljo Põllut ennast:

Meile, kes olime tõlketegevuse kaudu kursis kõige unemaga, ei pakkunud Tartu sõpruskond ega Moskva põrandaalused mitte midagi. Hoidsime nendest fossiilidest eemale. Ka kollaaž ning abstraktsus polnud siis meile enam mingi uuenduslikkus (Põllu 2002).

Tiiu Talvistu väitel mängis Kaljo Põllu kui rühmajuht, ideoloog ja pedagoog Lääne pop- ja opkunsti eksperimendid oma loomingus läbi kõige didaktilisemalt, nii et neid võiks kasutada praegu eesti kunstiajaloo õpikus puhaste stiilinäidetena (Talvistu 1997: 11). Visarite omaaegsed räiged teema- ja vormilahendused ning atraktiivsed kujundid mõjusid küll tollases kontekstis šokeerivalt, kuid sellest hoolimata jäid Kaljo Põllu popist ja opist inspireeritud tööd lääne avangardi kunstikogemust kopeerivaks. Ka intrigeerimisastmel jäid nad mitu sammu maha pisut nooremate SOUP 69 liikmete Leonhard Lapini, Andres Toltsi ja Ando Keskküla taiestest - viimased püüdsid Läänest peegelduvat kunstitunnetust tõlkida eesti kunsti konteksti, saavutades arvestatavaid tulemusi nn sovjet-popi ehk liit-popi vallas.

Visarite üheks erijooneks oli aktiivne huvi väljaspool suletud nõukogude süsteemi leiduvate kunstiteoreetiliste tekstide vastu. 


\section{Riin Kübarsepp}
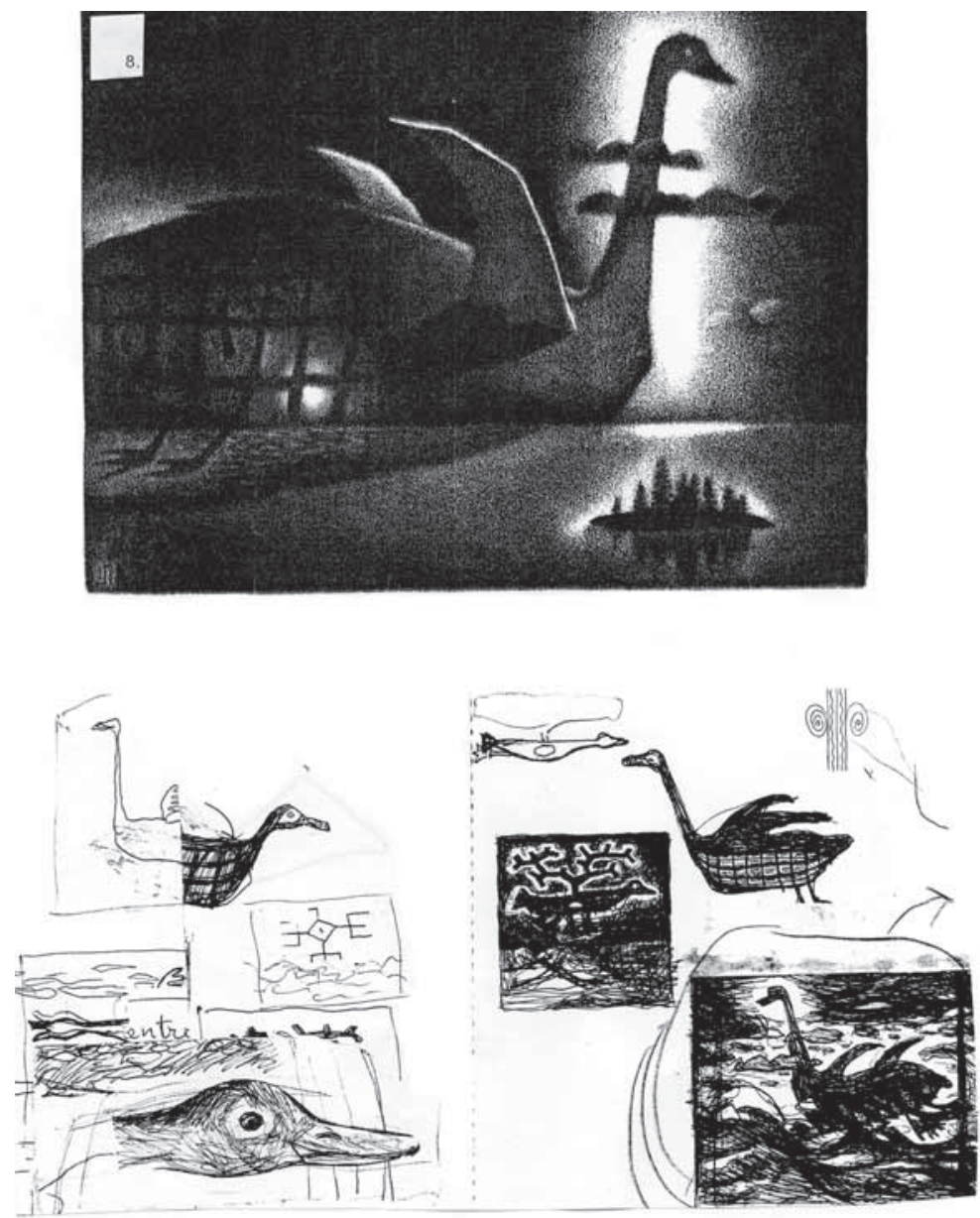

Joonis 6. Kaljo Põllu. "Pesapaika otsiv veelind" (sarjast "Kalivägi"). Metsotinto. 37x49,1 cm. 1978. Pildi all sellel kujutatud detailide visandid. Pliiats.

Selle praktiliseks näiteks on Visarite käsikirjalised kunstiraamatute tõlked (Herbert Read, Aldo Pellegrini, Bernard Dorival jt).

Sirje Helme väitel olid Visarid ainus sõjajärgne rühmitus, kes määratles end manifesti kaudu ega häbenenud selles kirjutada rahvusliku kultuuri omapärast, harmooniast ja tasakaalust (Helme 
1997: 4). Juba sellega defineeris K. Põllu oma hoiaku Visarite ideoloogina, millest oli vaid lühike samm soome-ugri mütoloogilisse ainevaldkonda.

1960. aastatel valitses Tartu ja Tallinna kui kunstilinnade mentaliteedi konflikt. Pallas kuulus Tartule, ANK ja SOUP aga Tallinnale. Pallase tähenduse taastamine tähendas S. Helme sõnul tõe otsimist minevikust ja endasse sulgumist, teadlikku eemaldumist oma kaasajast, optimistlikest kuuekümnendatest. Tartu hakkas sel hetkel tähistama konservatiivset, Tallinn uuendusmeelset kultuuri. Samas tõdeb S. Helme Visarite kataloogi eessõnas, et Visarid kuuluvad küll Tartusse, kuid nende kaasaminekut ja kaasasolekut uue kultuuriga on alati tunnistatud (Helme 1997: 4).

S. Helme meelest olid Visarid ometi kunsti üldpildis nagu kõrvalseisjad ja rühmitus tervikuna ei pääsenud neljandaks müüdiks Pallase, ANK '64 ja SOUP 69 kõrvale.

Siinkohal vaidleksin vastu, sest Kaljo Põllu ei suutnud küll ehitada müüti müüdile, luua Tartu Pallase-kultuse atmosfääri uut müüti, kuid suutis rühmituse kaudu olla avatud uuele kunstiesteetikale, kogu vaimsele atmosfäärile, mis tekkis suhtlemisel oma ajaga valitsevast ühiskondlik-poliitilisest ruumist hoolimata.

Visaritel polnud eelkäijaid ja neil polnud ka järgijaid, sest nn Tartu kunstikoloonia ei arendanud nende radikaalseid ideid edasi ja kunstikabineti mõjuvõim noore intelligentsi üle ununes ühes Visarite lahkumisega.

Murrang toimus 1973. aastal: kunstikabinet oli sunnitud kolima ülikooli peahoone ja Werneri kohviku lähedusest Tiigi tänava vanasse ühiselamusse. Kunstikabineti roll ja Kaljo Põllu autoriteet Tartu noore intelligentsi hulgas oli kasvanud planeerimatult suureks, lähenedes juba vabaakadeemiale ja sealne õhustik humanitaaride klubile.

Kaljo Põllu ainulaadne suhe moodsa kunstiga lõppes 1972. aastal pärast op- ja popkunsti perioodi, samal ajal lõppes ka Visarite tegevus kunstirühmitusena. Tema lahkumisega lõppes ühtlasi ka kunstikabineti eriline tähenduslikkus.

Visarite puhul võib küll rääkida suuremast lugemusest, võõrkeelse kirjanduse ja kunstiteooria hankimisest ja sellega tutvumisest, kuid see-eest puudus neil piisav visuaalne materjal, mis sellele sekundeerinuks. Tõnis Vindi ringkonnas Tallinnas liikus rohkem ajakirju ja koos sellega pildilist informatsiooni, mis on andnud S. Helmele põhjust rääkida nn reproavangardist (Helme 1997: 6). 


\section{Riin Kübarsepp}

Visarite kunstirühmitus oli kunstikabineti loogiline järg, kus Kaljo Põllu oli ühendanud nii kaasaegse kunsti ajaloo- ja teooriaõppe, avatud kunstiõppesüsteemi ning laiapõhjalise ja loomingulise kunstirühmituse, kelle pretensioon tegelda kaasaegse kunstiga põhines professionaalsel suhtumisel loomingusse. Seega oleks S. Helme väitel jäänud Kaljo Põllu töö Visariteta poolikuks - kunstikabinetil oleks puudunud praktikasse viidud tegevuse mudel (Helme 1997: 8).

Visarite manifesti kirjutas Kaljo Põllu 1971. aastal, mil tundus, et Visarite kui loomingulise rühmituse aeg on lõppemas, formuleerides tagantjärele kokkuvõtvalt seda, mis praktikas oli juba teostatud.

Manifestis tõstatas K. Põllu küsimuse Tallinna suhtest Tartu kunsti. Viimases kritiseeritakse näilise heaoluühiskonna massikultuuri ja kommertskultuuriga kaasas käivat manerimi ja epigoonluse kriisi. Manifestis on korduvalt rõhutatud, et Visarid pole lääne kunstivoolu jäljendajad. Kunstniku eesmärgiks pole sealjuures pelgupaiga otsimine ja selja pööramine maailmale, vaid pidev kasvav osalus ajastu tõsiasjades. Manifesti üks osa formuleerib rahvusliku identiteedi võimalikkuse, mis viitab juba Kaljo Põllu omajuurse soome-ugri kultuuri otsingutele. Samas võib mõnda esitatud printsiipi pidada õigusega vastavalt Heie Treieri sõnastusele modernismi utoopiateks, mis kajastuvad modernismi idees tulevikuühiskonnast ja uutest tehnoloogiatest.

Ometi jääb nii Visarite kui ka SOUP 69 kümnendivahetuse kunstikogemus paljuski mänguliseks vahepalaks, millest suhteliselt kiiresti üle libisetakse. Äärmuslikelt assamblaažidelt, ready-made'idelt ja uudsete materjalide kasutuselt liigutakse kiiresti traditsiooniliste kunstiliikide maali ja graafika juurde, kus hillitsetumalt jätkatakse avangardistlikke uuendusi. T. Talvistu väitel kaob töödest räige konfrontatsioon ja avalik mässumeelsus ümbritseva tölpluse suhtes (Talvistu 1997: 12).

Miks Visarid lõpetasid kooseksisteerimise? Harry Liivrand on seda põhjendanud Herbert Readi väitega, et käesoleval sajandil on kunstnike rühmitumine ajendatud sageli pigem praktilistest kui ideelistest motiividest (läbilöömine kunstiilmas); rühmituste eluiga ei ületa reeglina 4-5 aastat ja nad hääbuvad siis, kui enamiku liikmete individuaalsus end maksma paneb. Järeldus on tehtud küll Lääne-Euroopa kunsti vaatluse põhjal, kuid sobib Eestissegi, täpselt Visarite kohta. 


\section{Riin Kübarsepp}
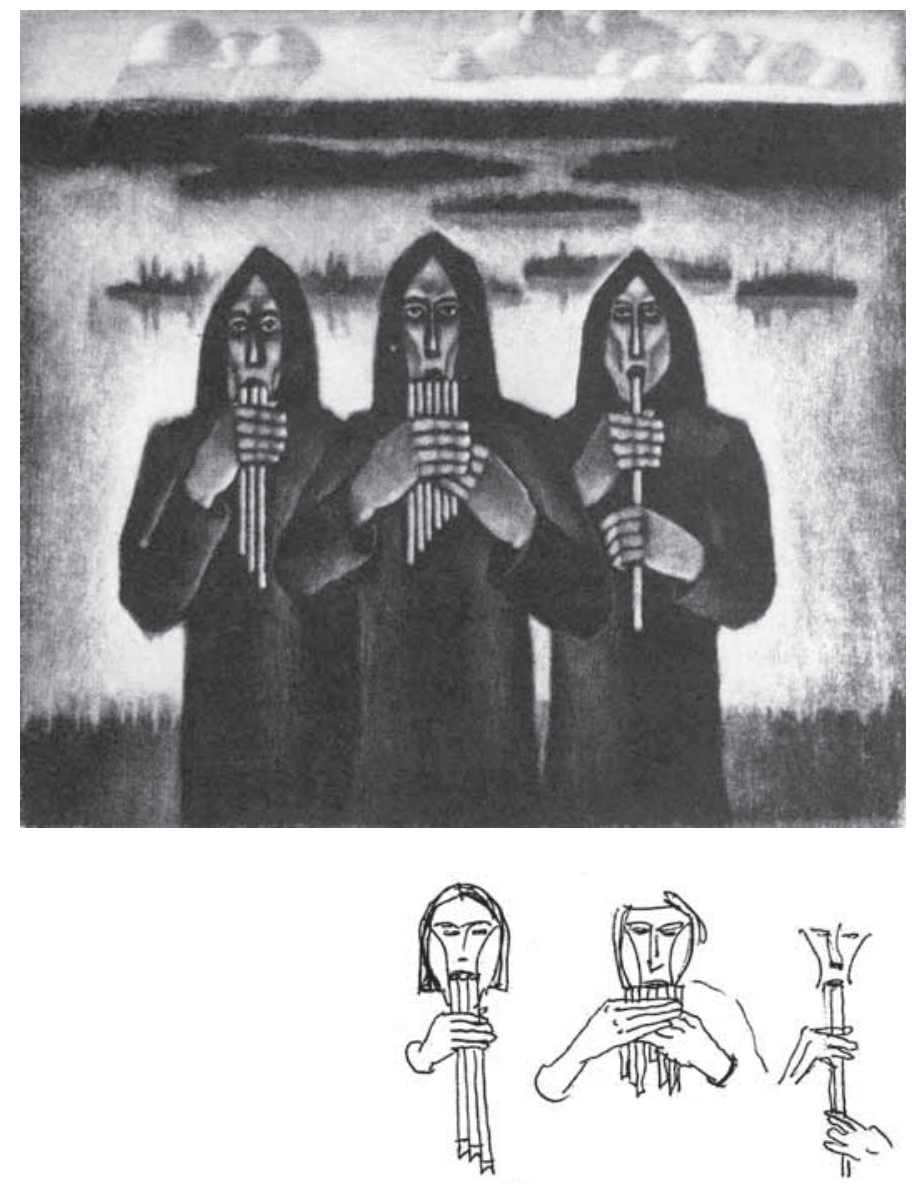

Pänese emale
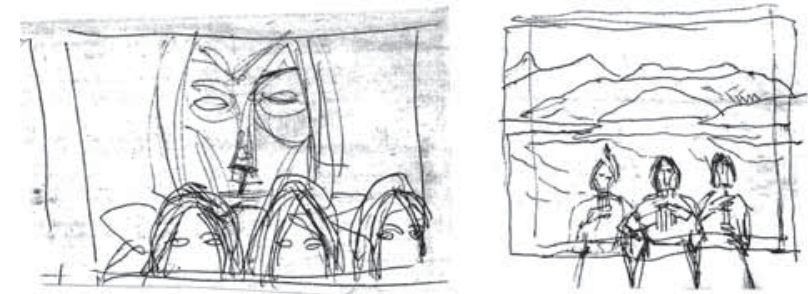

Joonis 7. Kaljo Põllu "Maa-emale" (sarjast "Kodalased"). Metsotino. $38,5 \times 41,5 \mathrm{~cm}$. 1975. Pildi all sellel kujutatud detailide visandid. Pliiats. 


\section{Riin Kübarsepp}

\section{Paradigmamuutus 1970. aastate kunstis}

Tšehhoslovakkias suruti nn Prahva kevade järel, 1968. aastal maha Alexander Dubčeki nn inimnäoline sotsialism ja asendati see brežnevliku reaalse sotsialismiga.

Jaak Kangilaski väitel oli tolleaegne Nõukogude Liidu kultuuripoliitika siiski stalinlik-ždanovlik, mitte readilik-greenberglik. Ants Juskega (Juske 1997) tuleb aga nõustuda selles, et readilik-greenbergliku "mudeli" mõju oli Eesti NSVs tugev alates 1960. aastatest peaaegu nõukogude aja lõpuni.

Heinz Valgu väitel iseloomustab 1970. aasate komparteid kunagise range distsipliini kokkuvarisemisest tulenev parteilise ustavuse teesklus. Ideoloogia ei olnud parteilastele enam elujuhiseks, vaid karjääriredeliks. Ajastu kõlbelise laostumise sümbol oli poolsurnud joodik Leonid Brežnev, kelle üle irvitasid nii rahvas kui ka parteifunktsionärid. Eesti NSVs lisas sellele allakäiguõhkkonnale masendust laialdane venestamiskampaania koos tohutu migratsiooniga. Pakazuhha võimaldas aga eksponeerida "suure ajastu pulssi" iseloomustavate tööde varjus üsna vaba eneseväljendust (Valk 1997: 19).

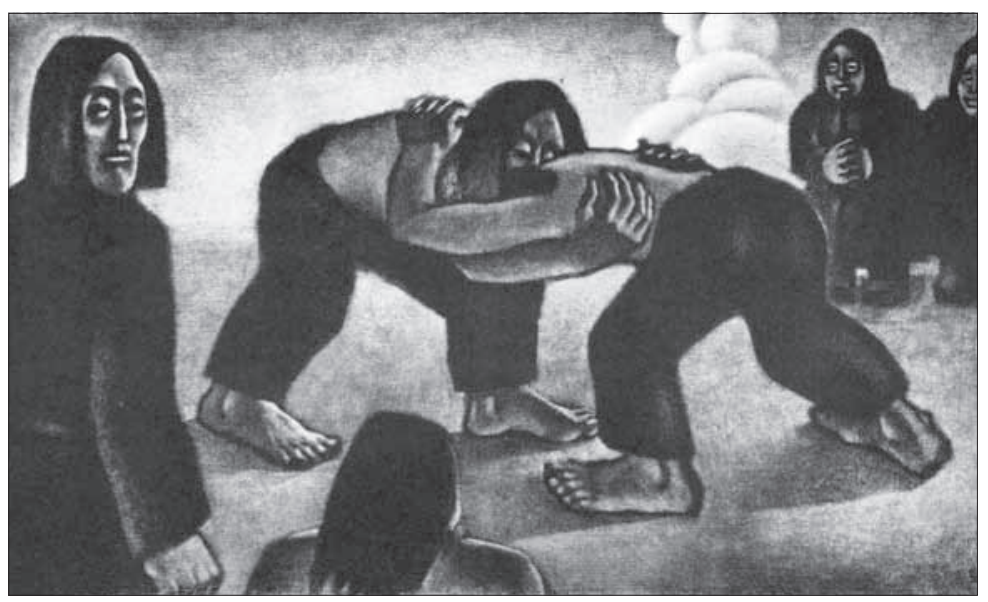

Joonis 6. Kaljo Põllu "Mehed" sarjast "Kodalased". Metsotinto. $30 \times 50,5$ cm. 1975. 
Kaljo Põllul kui tollase Tartu Riikliku Ülikooli kunstikabineti juhatajal ja eestvedajal oli teravaid kokkupõrkeid EKP Keskkomiteega ja aruandmisi Eesti Kunstnike Liidu juhtkonna ees. Viidi ju tõenäoliselt just sellepärast ka kunstikabinet kesklinnast eemale Tiigi tänava ühiselamusse, mis mõjutas märkimisväärselt kabinetis valitsevat ühtset vaimu ja kunstitegevust. Pärast neid muutusi lahkus Kaljo Põllu vabatahtlikult Tartust ja asus tööle Eesti Riiklikusse Kunstiinstituuti. Kõik see andis omamoodi löögi kunstniku maailmavaatele ja kõigutas tema seniseid tõekspidamisi lääne uuenduslike kunstivoolude suhtes. Pööre eelnevalt loominguteelt oli kardinaalne ja lõplik.

Poliitiline sulaaeg oli 1970. aastate algul asendumas üha stagneerunuma ja jäigastuvama poliitilise süsteemiga, mis püüdis ka loomingulist noorsugu range kontrolli alla saada. Eesmärk oli tagada absoluutne kontroll kunstisündmuste ja näituste üle, andes samas Kunstnike Liidu ja Noorte Kunstnike Koondiste kaudu kunstnikele siiski esinemisvõimalusi. Nüüd oli iga autori enda teha, kuivõrd ta arvestas žürii nõudmisi, et pääseda eksponeeritavate hulka. Ilmselt oli selle aja inimestesse seesmine kontroll juba sisse kodeeritud, nii et sisult ja vormilt radikaalsemad tööd jäeti näitustele esitamata ning paljudel lihvis süsteem ise n-ö teravnurgad kumeraks (Talvistu 1997: 12).

1970. aastatel leidis ka Läänes aset pettumine pealtnäha optimistlikes utoopiates. Sellega kaasnes ka pettumine demokraatias ja progressis, mida süvendasid kosmoseprogrammide ebaõnnestumine ja ülemaailmne naftakriis. Kasvas retro- ja nostalgiahuvi rahvakultuuri vastu, mida võimendas hipide idee pöörduda ära kõikehõlmavast tsivilisatsioonist. Seega võib Kaljo Põllu tööde soomeugrilike algjuurte temaatika sisuliseks ajendiks ja võimendajaks pidada just hipide tärkavat etnonägemust.

\section{Murdepunkt Kaljo Põllu loomingus}

Kui 1960. aastatel püüti tuge leida läänelikkust ihalevatest meeleoludest, siis järgneval aastakümnel kerkis esile uus tegutsemissuund. Viimase tunnusjooneks kujunesid pürgimused leida üles eesti vaevalt saja-aastase lääneliku ilmega professionaalse omakultuurikihi alt sellele eelnenud vastupidavam ja modernismist veel rikkumata aluspind ehk esialgne, kõiki soome-ugri rahvaid ühendav vaimulaad. 


\section{Riin Kübarsepp}

Oma edaspidises loomingus on Kaljo Põllu lähtunud just loetletud arusaamadest eesmärgiga arendada edasi kaasaegse eesti kunsti omapära ja elujõulisust, millega käib kaasas tema soov vabaneda väikerahva kultuurilisele toimimisele omasest alaväärsustundest.

1970. aastate alguses hakkas K. Põllust kujunema iseseisev kunstnikutüüp, kes hakkas kinnistuma oma konkreetses, väljakujunenud laadis, distantseerudes Läänest õpitud radikaalsetest kunstieksperimentidest. Nõnda on ta suunanud oma peatähelepanu soomeugrilaste kunstiloomingule läbi aegade ning otsinud selle üldinimlikku sisu, omapärast kunstilist alget ja ürgset kosmogoonilist tausta.

Soome-ugri uurimisreiside ja ekspeditsioonide korraldamise idee tekkis Kaljo Põllul juba 1970. aastate alguses Tartu ülikooli kunstikabinetis töötamise ajal. Selle idee ajendiks oli professor Paul Ariste väide, et fennougristika kui teadus ei piirdu üksnes keele, rahvaluule, ajaloo ja etnoloogiaga, vaid haarab ka kunsti. Kuid ülikooli tollasel juhtkonnal ei olnud arusaamist ega soovi soome-ugri rahvakunsti alaseid uurimisreise Venemaale rahaliselt toetada. Hiljem, kunstiinstituudi õppejõuna avanes K. Põllul tänu sealse rektori professor Jaan Varese suhtumisele ja rahalisele toetusele võimalus alustada oma aastaid idanenud unistuste täideviimist (Põllu 1999: 31).

Kaljo Põllu on olnud tihe kontaktide siduja rahvusvaheliselt tuntud fennougristidega. Suurt abi kunstnikule tema soome-ugrikeskse maailmavaate kujunemisel oli ka Ants Viiresel Ajaloo Instituudist ning Ago Künnapil ja Tõnu Seilenthalil Tartu Ülikoolist. Tähtis osa on olnud juba aastaid kestnud teadmiste vahetamisel selliste rahvusvaheliselt tuntud fennougristidega nagu keeleteadlased Ilse Lehiste Ohio ülikoolist USAs, professor Robert Austerlitz Columbia ülikoolist USAs, Tasuku Kikugawa Kobe ülikoolist Jaapanis, aga ka antropoloog Kinga Ery Budapesti ülikoolist Ungaris. Enamik suhetest sai alguse 1985. aastal Komimaa pealinnas Sõktõvkaris IV rahvusvahelise fennougristika kongressi ajal. Kaljo Põllu sõnul võttis sellest osa ekspeditsioonide seitsmeliikmeline esindus, viies kaasa teaduslike materjalide alusel valminud tööde näituse (Põllu 1999: 32).

K. Põllu suurte graafiliste sarjade aine pärineb aastatel 19621975 koos Tartu ülikooli üliõpilastega korraldatud ekskursioonidelt erinevatesse Eesti paikadesse. Just sealt sai alguse graafiliste lehtede sarja "Eesti maastikud" idee. Sealjuures väidab kunstnik enesekindlalt, et neilt pole mõtet otsida mingit konkreetset maakohta, pi- 
gem on piltide näol tegu mälu koondtulemusega (Raudam 1995: 42). Üldinimliku sisuga pildid sündisid alates 1978. aastast Kaljo Põllu juhendatud kunstiülikooli ekspeditsioonidel soome-ugri rahvaste juurde kogutud materjalide ja teadusliku kirjanduse lugemise tulemusena.

Seoses ekspeditsioonidega keskendus ta sel ajal põhjalikult ürgaja kunsti ja kultuuri tutvustavatele tekstidele. Lõuna-Euroopas elanud paleoliitikumi mammutiküttide kunsti uurides tõdes ta, et nende kujutluses oli maailm tasane ja ühekihiline. Hiljem, mesoliitikumis tekkis inimesel ettekujutus kolmekihilisest maailmast, mis koosnes Päikese, Kuu ja tähtede taevast, metsade, veekogude ja jahiloomadega maast ning vee- ja maa-alusest maailmast (Põllu 1999: 10).

K. Põllu hakkas oma töödes kasutama märkide ridu (romb punktiga keskel, haakromb, kolmnurk jt), mis kehastavad tuntumaid loodusobjekte ja on arvatavasti mõistetavad kõigile. Selliselt oli inimlik kujutlusvõime näiliselt surutud kitsastesse raamidesse, kuid kujundite sisu oli seda avaram. Tõenäoliselt tekkisid need tinglikud algkujundid üheaegselt mõistetega III ja IV aastatuhandel eKr.

Päikesekujund on omane nii Äänisjärve kaljujoonistele kui ka mis tahes neoliitilistele kultuuridele. Kõige vanemaks peetakse loomismüüti, mida esiajaloolises kunstis väljendati kahe taevase põdra abil. Põdra kujutised on läbivad graafilistes sarjades "Kodalased" ja "Kalivägi".

Eelajalooliste hõimude dualistliku maailmapildi kohaselt on ka K. Põllu maalidel kujundid äärmuseni lihtsustatud. Kunstnik ise nimetab neid ürgalgkujunditeks, kuid embleemilaadselt kujundatud õlimaalid meenutavad tihtipeale 1960. aastail Eestis läbi elatud pop- ja opkunsti perioodi.

Tripolje kultuuri arheoloogiliste leidude uurimisel on selgunud, et algeliste põlluharijate kujutluses koosnes maailmaruum tõenäoliselt kolmest üksteise peal olevast kihist: taimede, loomade ja inimestega asustatud maapinnast; Päikese, Kuu ja tähtedega alumisest, nähtavast taevast ehk õhuruumist ning nähtamatust, ammendamatute veevarudega ülemisest taevast. Sellepärast eraldab ülemist ja alumist taevast ornamendis sageli maa märk - kolmnurkade rida (Põllu 1999: 12). Analoogilist maailmaruumi kolme üksteise peal asetseva kihina kujutab K. Põllu tihti ka oma graafilistel lehtedel ja maalidel.

Nende kolme maailmakihi juhtimine oli ilmselt ühe üleloomuliku olendi, tinglikult Suure Taevase Esiema (ka Maailmaruumi Näh- 


\section{Riin Kübarsepp}

tamatu Jumalanna) käes. Sellise ettekujutuse tekkimine langes tõenäoliselt ühte emajärgse sugukondliku korra õitsenguga. Suurt Taevast Esiema ei juletud kujutada tervenisti, sest see oli tabu (Põllu 1996b: 12). 1970. aastate keskel kujuneb just Suur Taevane Esiema nii kompositsiooniliselt kui ka sisuliselt K. Põllu metsotintosarjade primaarseks figuuriks.

\section{Kaljo Põllu kui visuaalse rahvaluule kollektsionäär}

Kogu inimkonna tänane arenguaste määratakse lääneliku ühiskonna teadusliku ja tehnilise arengu astmega. Ka 20. sajandi esimesel poolel oli valitsev arusaam, et inimese elu läheb aina paremaks. Alles sajandi teisel poolel võib täheldada tõsisemaid kahtlusi lineaarse ajalookäsitluse suhtes. Juba 1920. aastatel juhtis Saksa kultuurifilosoof Osvald Spengler tähelepanu lääne tsivilisatsiooni varjukülgedele, Õhtumaa allakäigule. Vastandudes lineaarsele progressiideele rajab ka K. Põllu oma kunsti etnograafilisest minevikust võetule.

Vaieldamatu keelesuguluse kõrvale otsib Kaljo Põllu ka kõiki uurali rahvaid ühendavat kultuurisilda, mille oluliseks osaks on arheoloogiline leiumaterjal ja rahvakunst. Esimesena püüdis 19. sajandi lõpul anda soomeugrilaste arheoloogilisest ainestikust ülevaadet Johan Reinhold Aspelin, hiljem taotles seda Aarne Mikael (Michael) Tallgren. Soome-ugri võrdleva etnograafilise uurimuse algatas 19. sajandi lõpul ungarlane János Jankó, seda jätkasid Uuno Taavi Sirelius, Albert Hämäläinen ja Ilmari Manninen (Põllu 1999: 14).

Kaljo Põllu viimase kümne aasta jooksul valminud töödes on kasutatud palju obiugrilaste piltkirjast pärit ornamente. Obiugrilaste ornamendi vanimad motiivid on rangelt geomeetrilised - ruudud ja kolmnurgad. Hiljem on nendest välja arenenud kaks põhilist ornamenditüüpi: lintornament ja medaljoni tüüpi ornament. Oma töödes kasutab K. Põllu tihti etnograafilist ornamenti, mis täidab vaid dekoratiivset osa. Obiugrilased kasutavad lintornamenti, mille motiivid on välja kasvanud põhjapõdrasarvede, jänesekõrvade ja lindude külgvaates kujutistest, peamiselt rõivaste, jalatsite ja kasetohust tarbeesemete kaunistamiseks. Erilise tähendusega on aga mansidel linnukujutised. Uurali rahvakultuuris oli üks tuntumaid tootemloomi ürgse maailmakõiksuse loomismüüdiga seotud veelind, millest arenes välja veelinnukultus (Põllu 1999: 22). Ka pardi- 
ja hanekujund on kinnistunud kanoniseerituna K. Põllu soome-ugriteemalistes töödes.

Oma ligi kuue aasta taguses artiklis on Kaljo Põllu tõdenud, et aastatuhandeid on kujutava kunsti üheks tähelepandavamaks ülesandeks olnud kaduva tegelikkuse vangistamine ja ajahetke kestuse näiline pikendamine (Põllu 1996b: 12). Sellisest suhtumisest, arusaamadest ja maailmanägemusest on ta juhindunud kogu oma pikal loometeel: 1973. aastal "Kodalaste" sarjas, ajavahemikus 1978-1984 "Kaliväe" seerias, 1991. aastal lõpetatud "Taeva ja maa" metsotintolehtedel ja 1994. aastal valminud komplektis "Kirgastumine". Kunstnik on toonud vaatajale lähemale soome-ugri rahvaste mütoloogia.

Kaudselt on Kaljo Põllu aastatepikkune tegevus võrreldav Oskar Kallase tööga, kes esmakordselt viis eesti rahvaluule teadustööna rahvusvahelisele tasemele. K. Põllu soome-ugri ekspeditsioonide materjalie võib võrrelda ka Jakob Hurda rahvaloomingukogudega. Analoogse tööga etnograafilise varamu säilitamisel on tegelnud Ferdinand Linnus ja Harri Moora. K. Põllugi tegi seoses oma soomeugri ekspeditsioonidega tihedat koostööd tolleaegse Eesti NSV Riikliku Etnograafimuuseumiga Tartus (praegune Eesti Rahva Muuseum). Ta lähtus sealjuures professor P. Ariste väitest, et fennougristika ei piirdu ainult keelega, see on ka kunsti, mõtlemise ja olemise probleem. Ta jätkab seega Kristjan Raua üritust nii rahvateaduslikus kui ka aatelis-loomingulises mõttes (Põldmäe: 1984: 16).

Ürgsemaid igavikulisi motiive loodusrahvaste mütoloogias on ilmasammmas, mis oli seotud taevavõlvi saladusliku tiirlemisega. Töös "Ilmasammas" meenutab see laasitud kuuske - läänemeresoomlaste ilmasamba algkuju ja püstkoja sammast.

Mitmes kultuuris on kosmogoonia üheks motiiviks tuli, mis oli algelement nagu vesigi. Samas käsitab selline müütiline maailmapilt loodust kui pühadust, olemata sugugi tingimata usulise iseloomuga. See lähtus jahimehe, kaluri ja karjakasvataja eluvaatest, et maailm nende ees ja ümber on piiratud ja hingestatud: maa on loom, kes kannab kõike, ja taevas on lind, kes varjab kõike oma tiibadega.

\section{Soome-ugri mõttelaadist}

Jaan Kaplinski väitel on Hiina vana, eriti budismieelne filosoofia ilmselt ainus põline mitteindoeuroopa filosoofia. Kui muidugi seda mõttetarkust filosoofiaks nimetada. Siin võib filosoofiaks nimetada 


\section{Riin Kübarsepp}

lihtsalt seda, mida meie nimetame maailmavaateks saksa Weltanschauungi eeskujul, midagi, mida mõtles ilmselt ka Friedrich Nietzsche oma sõnadega in die Welt blicken (maailma vaatama) (Kaplinski 2002: 231).

Hispaania vallutuste ja kolonisatsiooni eelsel ajal ei olnud filipiinlastel linnu, kirjakeelt ega loomulikult ka mitte filosoofiat meie mõttes. J. Kaplinski sõnul iseloomustab sama ka vanu eestlasi. Ta toetub soome-ugri omakultuuri lätete analüüsil filosoofi, teoloogi ja antropoloogi Leonardo Mercado ${ }^{1}$ kirjutisele "The Filipino Mind", kus autor lähtub filipiini filosoofias vaid keeleväljendustest, väljendusmallidest ning keele ja folkloori suhetest (Kaplinski 2002: 233). See on midagi, milles võib näha ka potentsiaalset filosoofiat, filosoofiat eos.

See meenutab tükati Oskar Looritsa ja Uku Masingu kirjutisi eestlaste vanadest uskumustest ja kujutelmadest, mida viimased küll filosoofiaks ei nimetanud, mida aga $\mathrm{O}$. Loorits kaldus nägema omamoodi ürgse ja sügava elutarkusena. Ago Künnapi sõnul jääb soome-ugri rahvaluule ja usundi võrdlev esitus fennougristidele endiselt metodoloogiliseks väljakutseks, soome-ugri rahvastele aga alati väärtuseks võitluses kultuuriidentiteedi ja etnilise edasikestmise eest (Künnap 1996: 2023).

Visuaalselt võib seda väide illustreerida K. Põllu graafilise sarjaga "Kalivägi”. See algab kosmogoonilise, maailmatekkelise müüdiga, põigates tagasi Uurali ja soome-ugri aega (algmeri ja pesapaika otsiv veelind). Kõige vormitinglikumaks pildiks "Kaliväe" sarjas võib pidada "Maailmamuna", eelkõige selle mütoloogilist sisu - maailmakõiksuse tekkimist metspardi munast (kirjeldatud ka "Kalevala" 1. runos).

Sõnast "kali" oli juttu juba Lennart Mere raamatutes Hõbevalge (1976) ja Hõbevalgem (1984). P. Ariste on uurinud selle sõna päritolu ja tähendust, väites, et põhjaeestiline murdesõna "kali" on esinenud juba 18. sajandil ja tähendanud tugevat inimest. Sama mõistega ühenduvad ka isikunimed Kalev, Kalevipoeg, kalevite elupaik Kalevala, omadussõnad kalivägine ja kalijas. Ene Asu-Õunase sõnul võiks "Kaliväge" mahult võrrelda muusikalise suurvormiga, kuid samal ajal pidada ka pildiliseks hõimueeposeks. K. Põllu pole sealjuures mõelnud illustreerida ajalugu, vaid püüdnud seda omal viisil lahti mõtestada Lion Feuchtwangeri mõtte alusel, milles minevik ja olevik on analoogiad (Õunas 1984: 5).

Udmurdi tõelisest maailmapildist on kirjutanud udmurdi etnofuturismi esindaja Juri Kutšõran: 
Udmurdi maailmapilt põhineb eelkõige tule-, vee-, päikese- ja maakultusel, elu ja surma kujutelmadel, arusaamadel hingest, taevajumaluse kummardamisest. Selle aluseks on veelinnu (pardi, hane, luige) austamine, puude ja pühasalude kultus ning ettekujutus kolmekihilisest maailmakõiksusest (alumine, keskmine ja ülemine maailma). Part oli maailmakôiksuse keskmise kihi loomisel aktiivne osaline: just tema tõi maailmamere põhjast muda ja selle tulemusena kerkis Maa oma ainulaaduses ja mitmekihilisuses (Kutšõran 2001: 95).

Mütoloogiline süžee veelinnu sukeldumisest maailmamere põhja on tuntud kogu idapoolses Põhja-Euraasias, aga ka Põhja-Ameerikas.

Udmurdi šamanistlikku kosmoloogiat iseloomustab lisaks maailmakõiksuse jagamisele kolme ossa ka neid kolme sfääri ühendav telg. Selleks teljeks oli maailmapuu. Kõige arhailisem ühendaja

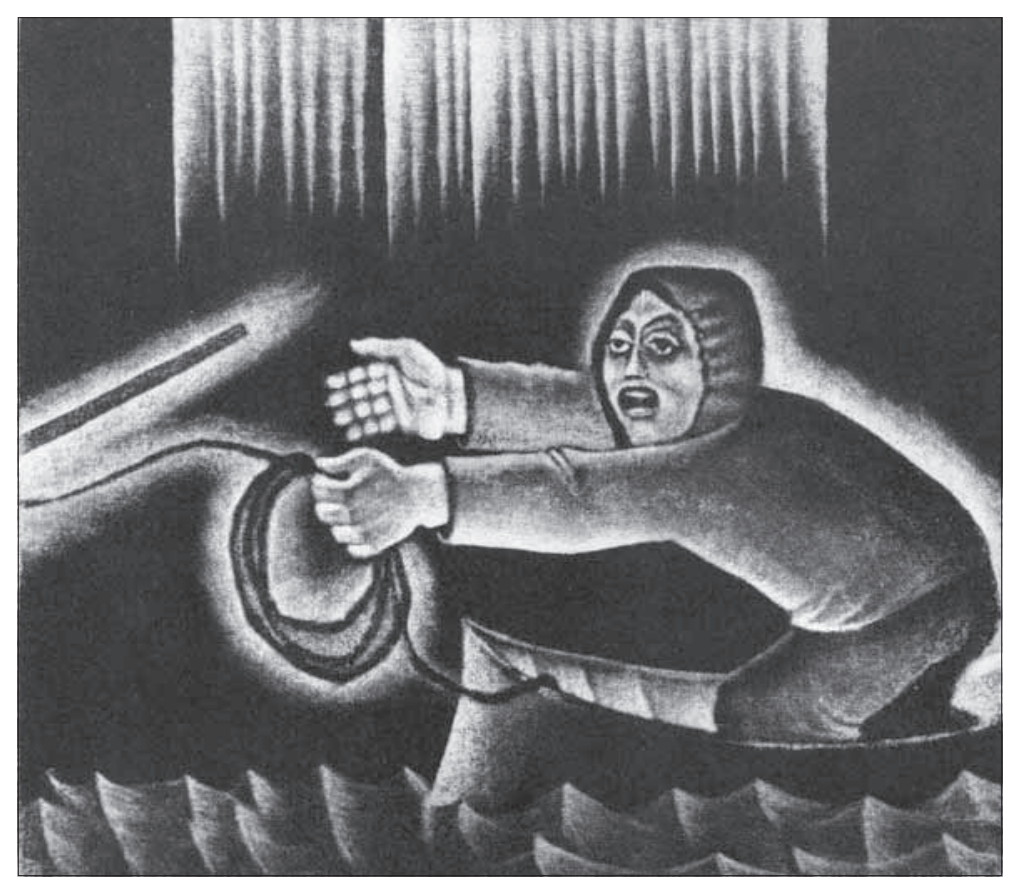

Joonis 9. Kaljo Põllu. "Hetk" (sarjast "Kodalased"). Metsotinto. $36 \times 41$ cm. 1975. 


\section{Riin Kübarsepp}

maa ja taeva vahel on kosmiline jõgi, mille läte asub lõunas (jumalate ilm, valgete jõudude pool), suue aga põhjas (teispoolne maailm, külma, pimeduse, kurjade vaimude pärusmaa) (Kutšõran 2001: 97).

Nii linnu- kui ka loomakujutised on K. Põllu töödes saavutanud omamoodi sümboli staatuse. J. Kaplinski sõnul on aga inimene kui märke kasutav loom juba ammusest ajast kaldunud nägema märke seal, kus neid tegelikult ei ole. Inimesele antud märkidena on tõlgendatud linnuhääli, välgulööke, tähistaevast, seamaksa või -põrna. Ka filosoofias on enamasti valitsenud usk sellesse, et maailma, tõeluse ja meie märgisüsteemide vahel on väga tugev vastavus ning märkide tähendused, maailma nähtused ja asjad moodustavad märkidele enestele analoogse diskreetse süsteemi, kusjuures nähtuste ja asjade vahel on võimalik teha selget vahet, tõmmata selged piirid. Oleme harjunud maailma nägema diskreetse või vähemalt palju diskreetsemana, kui ta tegelikult on. Nii võib öelda, et läänemaises kultuuris, nagu ka islamis ja judaismis, domineerib diskreetne pideva, määratu määramatu ja realism nominalismi üle (Kaplinski 2002: 235).

Nagu marginaalsed, alistatud rahvad sageli, on ka eestlased oma filosoofilises kultuuris ennekõike tõlkijad ja matkijad, eestikeelne filosoofiline diskursus on valdavalt võõrapärane.

Eesti keeles leiduvad abstraktsed sõnad ja terminid annavad J. Kaplinski sõnul tunnistust teistsugusest mõtlemisest. Tekib küsimus, milleks on niisugust teisitimõtlemist, teistsugust, defineerimata ja defineerimatute mõistetega mitteindoeuroopa filosoofiat vaja. Kas ei ole meie mõtlemine mitte progresseerunud just nimelt määramatusest määratuse, defineerimatusest defineerituse, piiritlematusest selgepiirilisuse poole ja kas ei ole just see selgepiiriline mõtlemine aidanud lääne inimestel luua oma filosoofiat ja teadust, mis on teinud meid vabamaks ja õnnelikumaks? Ometi leiab viimane väide tugevaid vastuargumente. Nii teaduse ja tehnika saavutused kui ka nende taga olev ideoloogia, loogika ja filosoofia on kaotanud osa oma prestiižist - läänemaine inimene ei usu enam, et tema mõtlemismallidega saab kõike seletada ja mõista. Ka J. Kaplinski kinnitab, et Läänemaadel valitsev mõtlemine on osalt süüdi selles, et maailm on kaotamas oma tasakaalu.

Vahest on see mõtlemine ise tasakaalust väljas. Kas pole siin omakorda sü̈̈di selle mõtlemise toetumine piiritlemistele, defi- 
nitsioonidele ja sedakaudu neisse sulgumine? (Kaplinski 2002: 247).

Soome-ugrilikule maailmaloomise müüdile võib paralleele tuua tantrismist. Tantrale on iseloomulik, et inimkeha nähakse kui maailmakõiksuse jäljendit. Sellise arusaama keskmeks on nõidusväeline looduskäsitlus. Arvatakse, et maailmakõiksus hingab nagu inimkeha ja inimkeha korrastavad kosmilise ühendamise ja eraldamise seadused (Rawson 1991: 218). Peale maagilise looduskäsitluse ja seksuaalse alkeemia on tantra ruumiline astroloogia. Taevas ja maa, päike ja kuu, tähed ja planeedid on ühtlasi inimkehad oma katkematus rütmilises konjunktsioonis ja disjunktsioonis. Samal ajal on inimkeha tähtkujude märkide asetustest täidetud ruum. Tantra tõlgendab sõnasõnaliselt muinasaja kõnekujundit "tähed" kui "märgid", "saatused" (Rawson 1991: 216). Ruumilist astroloogiat kasutab K. Põllu ka oma graafilistel lehtedel "Taevas ja maa”.

Võibolla nüüd, kui meie mõtlemine ja meie kujutlused ei saa aina sagedamini aru maailmast, mille seesama mõtlemine on loonud, on meil eriti oluline mõista iseennast, oma mõtlemist (Kaplinski 2002: 248).

J. Kaplinski arvab, et ka soome-ugri mõtlemise laad, protofilosoofia, võiks õpetada midagi läänemaailmale. Visualiseeritud kujul peegeldavad sellist mõttemaailma eriti K. Põllu loodud "Kodalaste" rustikaalsed vormid. J. Kaplinski eelnevad mõttekäigud põhjendavad sealjuures ka K. Põllu soome-ugrilisuse otsingute olulisust.

1989. aastal valminud mütoloogiline sari "Taevas ja maa" koosneb 27 lehest. Analoogiliselt "Kaliväele" on ka "Taevas ja maa" värviline, mis annab töödele erilise maalilisuse. Ka nende töödes on pildikeel lihtne, puhas ja stiilne. Tekib kahtlus, et mida lihtsamad ja primitiivsemad on vormid näiliselt, seda keerulisemad on nad tegelikult. Sealjuures peidavad K. Põllu tööd endas oma kindlat allteksti ja filosoofiat. Sarjas on kaks maailma, millest kõnelevad ka tööde pealkirjad: siinpoolne ja sealpoolne. Sealpoolne on taevas ja Linnutee, siinpoolne aga Maa-ema. Maad ja Taevast ühendav side on maailmapuu. Sarjas "Taevas ja maa" on kunstnik sidunud rohkesti vanu kujundeid ja märke ning selle kaudu nad põlistanud kui talle ainuomased (Asu-Õunas 1998). 


\section{Riin Kübarsepp}

\section{Nativismi olemusest}

Mis puutub nn omajuursesse kultuuri säilitamise ideesse, siis toetub Kaljo Põllu paljuski Jaan Kaplinski kultuurifilosoofilistele teooriatele ning nende kaudu omakorda Uku Masingu ja Oskar Looritsa kirjutistele soome-ugri pärandist.

Ometi ei sobinud juba 20. sajandi esimesel poolel O. Looritsa ideed eestlaste idaseostest, eestlastest kui ürgvanast kultuurrahvast ja üleskutsed arendada soome-ugrilist omakultuuri kokku eesti haritlaskonna selge euroorientatsiooniga. Üldiselt on aga O. Looritsa vaated toeks Juhan Luigale, A. H. Tammsaarele, Uku Masingule, Veljo Tormisele.

Eesti kultuuris on olemas nativistide ja läänlaste vastasseis. Nativiste ühendab usk sellesse, et eesti kultuur peaks olema omajuursem, toetudes põlisele ja päritule, mitte võõrsilt, eriti lääne poolt Euroopast imporditule. Sealjuures pole ime, et nii A. H. Tammsaare kui ka O. Loorits on huviga vaadanud Hiina poole, sest on ju Hiina kõrgkultuuride hulgas üks kõige omajuursemaid. ${ }^{2}$

Johann Gottfried von Herder tõi Euroopa mõtlemisse arusaama omakultuurist kui väärtusest ja sellest, et igal rahval, keelel ja kultuuril on oma hing ja vaim, mida tuleb hoida ja arendada ega tohi teiste vastu välja vahetada. O. Loorits püüdis aga selgitada ja kuulutada seda, mida herderlikult võiks nimetada eesti rahvavaimuks, kuid mida O. Loorits ise nimetas eestluseks, eesti vaimsuseks. Ta uskus, et eestlased on oma põhiolemuselt soomeugrilased ja ta pidas indoeurooplastelt - baltlastelt, germaanlastelt ja slaavlastelt - laenatut ikka mõnel määral sellele põhiolemusele võõraks. J. Kaplinski tõdeb oma kirjutistes ikka ja jälle, et O. Loorits on mitmeid kordi visandanud pildi sellest tema meelest eesti hingesügavuses elavast soomeugrilikust vaimsusest (Kaplinski 2000: 8).

Sellisest mõttelaadist mõjutuna muutub K. Põllu oma tööde kaudu tihtipeale folkloristiks-filosoofiks, kes püüab kohati naiivse rahvusideoloogina oma teostes visualiseerida klišeeks kujunenud väiteid oma rahva ainulaadusest. Samas on ka J. Kaplinski heitnud O. Looritsale ette, et viimane kaldus esindama dualistlikku vastandavat hoiakut, mida ta ise peab omaseks indogermaanidele. Sellist halvustavat suhtumist indoeurooplastesse jagab O. Loorits teise eesti teisitimõtlejast kultuurifilosoofi Uku Masinguga (Kaplinski 2000). 
Ometi võib nii Kaljo Põllu kui ka Oskar Looritsa töödest leida ajavaimust ning hetkelisest ühiskondlik-poliitilisest olukorrast õhutatud liialdusi ja lihtsustusi kõrvale lükates mõndagi tõsiseltvõetavat.

Tsiteerides jällegi J. Kaplinskit võib tõdeda, et O. Loorits oli esimene eesti mõtleja, kes ei näinud maarahvas vaid toorainet, materjali, millest Euroopa eeskujude järgi vormida tsiviliseeritud Euroopa rahvas:

Temale ei ole rahvaluule, rahvakombed ja rahvausk midagi alaväärtuslikku, eelajaloolist, vaid midagi, millest saavad õppust võtta ka linnastunud ja euroopastunud järelpõlved (Kaplinski 2000).

O. Loorits nägi eesti kultuuris aastatuhandetepikkust järjepidevust, mis lubaski tal oma monumentaalses saksakeelses monograafias Grundzüge des estnischen Volksglaubens nimetada eestlasi igivanaks kultuurrahvaks (uraltes Kulturvolk). Selline tavalisest kümneid kordi pikem ajaperspektiiv aitas tal näha eesti keeles ja meeles ühisjooni meist praegu üpris kaugete rahvaste keele ja meelega ning tõdeda, et euroopalik-indoeuroopalik kihistus, mis täna eesti kultuuris näib domineerivat, on midagi hilist ja pealiskaudset. ${ }^{3}$

Toetudes eelnevatele arusaamadele püüab ka K. Põllu mitmetes taiestes temale omase didaktilise lähenemise kaudu vihjata, et muistsed, meid Ida- ja Lõuna-Aasiaga ühendavad jooned on hetkel varjul ning neid ei taheta sageli märgata ega tunnistada.

\section{Dekonstrueerides kaljujooniseid Kaljo Põllu töödes}

Kaljo Põllu viimaste aastate jooksul valminud maali- ja graafikasarjades esineb väga tihti kujutisi kaljujoonistelt ja kivilabürindilaadseid elemente. Ta ise on figuure ja kaljujooniste sümboleid nii Soomes, Rootsis, Norras, Ida-Karjalas, mitmel pool Venemaal, Koola poolsaarel, Valge mere ääres, Uuralites kui ka Siberis põhjalikult uurinud ning üsna üks-üheselt ja äratuntavalt oma töödele üle kandnud.

Paljud elemendid sarnanevad nendega, mida näeb 1936. aastal Vladislav Ravdonikase leitud Vana-Zalavruga kaljujoonistepannool 


\section{Riin Kübarsepp}

Valge mere ääres. Vana-Zalavruga pannoo keskne osa kujutab tähistaevast, millele ka K. Põllu on tihti oma tööde rõhuasetuse suunanud. 1980. aastate lõpul läbi viidud vaatluste tulemusena väitis Helsingi ülikooli professor Niilo Valonen, et Vana-Zalavruga suured põhjapõdrad ja keskne põhjast lõunasse suunduv üle saja sõudjaga paadirivi koos sellega seotud mõnede väiksemate joonisterühmadega kujutab tähekaarti. Paadirivi üks ots jaguneb aga kaheks nagu Linnuteelgi (Põllu 1999: 18). Just Linnutee on üks Kaljo Põllu lemmikteemadest.

Karjala kaljujooniste lahtimõtestamisel on jõutud erinevatele seisukohtadele. Kaljo Põllu usub osalt Aleksander Linevski väitesse, et kaljujoonised kujutavad eelkõige möödaniku tegelikkust. Hoopis vastupidisele järeldusele tuli aga V. Ravdonikas, kes leidis, et need joonised on peaaegu eranditult fantaasialooming ja väljendavad esiajaloolise inimese kosmilist maailmamõistmist (Põllu 1999: 167). Kosmilisele maailmatunnetusele on oma teoreetilistes kirjutistes ja interpretatsioonides rõhunud Kaljo Põllugi, millele ta on lisanud ka kosmilise erootika. Helsingist $23 \mathrm{~km}$ läänes Kirkkonummi Vitträski järve rannikul paikneb geomeetrilistest kujunditest koosnev kaljumaalingute sari, kus esineb korduvalt narmasäärtega nelinurkse võrgu kujund. Tõenäoliselt pole see ornament, vaid on sümbol. K. Põllu väitel on seal tegemist piltkirja algega, kus kujutatakse naissoo tunnust. Samalaadseid märke kohtab ka kammkeraamika kultuuri saviesemetel ja lapi šamaanitrummidel (Põllu 1999: 172). Analoogset nn naissoo tunnust kohtab ka mitmel Kaljo Põllu graafilisel lehel.

Päikest on Kaljo Põllu oma mitmes töös kujutanud allegoorilise kujundina. Arvatavasti tugineb see vene uurija Konstantin Lauškini väitele, et Äänisjärve idakaldal kujutati päikest kui mütoloogilist olendit kord inimesetaolisena, kord looma tunnustega.

Äänisjärve idakaldal Suur-Guri saare kaljujoonistel näeb K. Lauškin aga Kalevala maailmamunateemalise loomismüüdi kujutamist. Sellel leiduvaid kujundeid on K. Põllu kasutanud ka mitmes oma soome-ugriteemalises metsotintosarjas (Põllu 1990: 20).

Ka labürinditeemat interpreteerib ta oma töödes laialt. Samal teemal on ta avaldanud artikleid ajakirjanduses. ${ }^{4}$ Oma väidetes toetub K. Põllu ajakirjas Eesti Loodus ilmunud Jaan Kaplinski ning Mart Rahi ja Tõnu Viigi samateemalistele artiklitele (Rahi \& 


\section{Riin Kübarsepp}
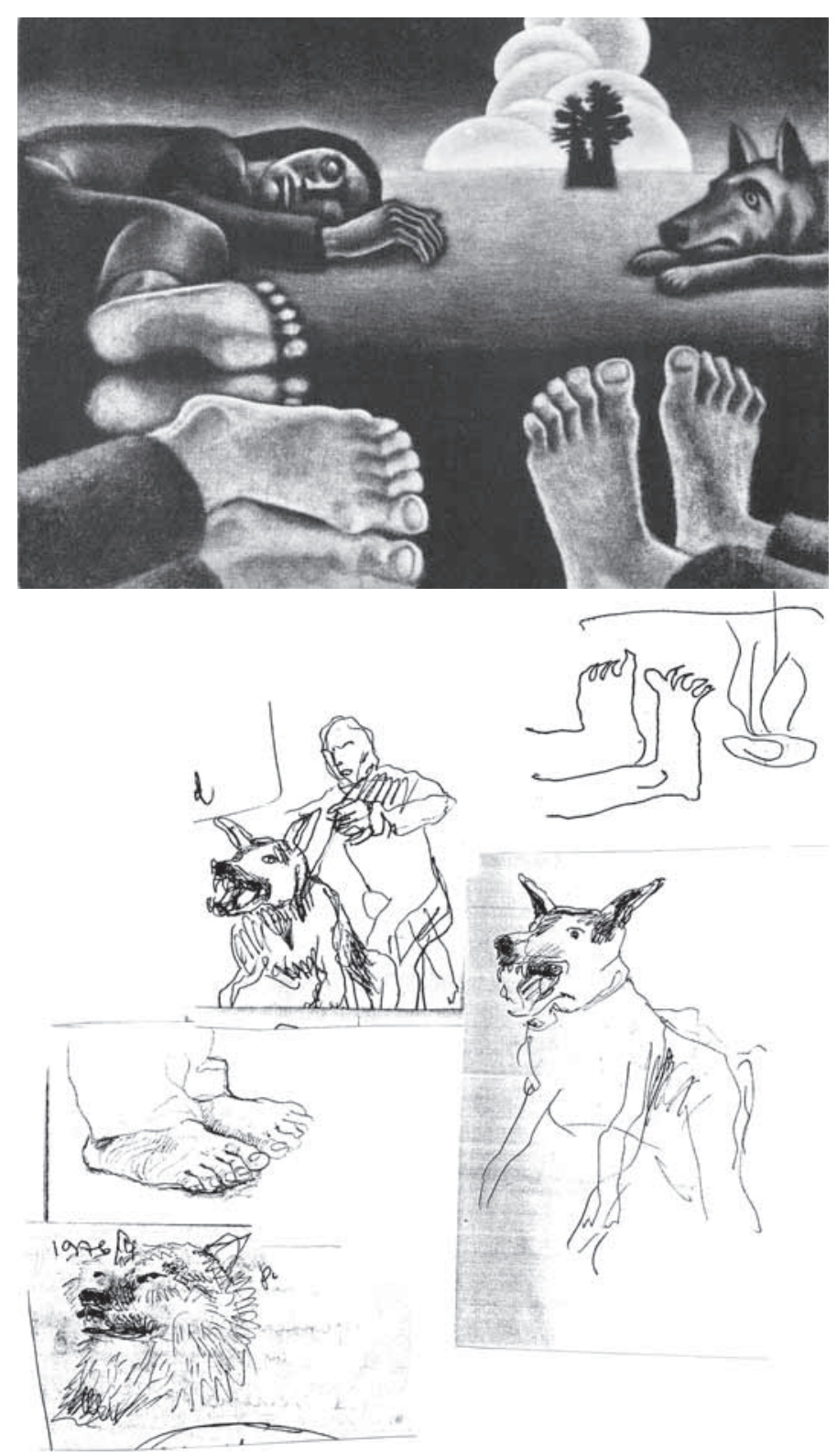

Joonis 9. Kaljo Pôllu. "Uni" (sarjast "Kodalased"). Metsotinto. $31 x 43,5 \mathrm{~cm}$. 1973. Pildi all sellel kujutatud detailide visandid. Pliiats. 


\section{Riin Kübarsepp}

Viik 1978). Sealjuures pole teema K. Põllule sugugi võõras, sest labürindi kujundiga manipuleerib ta juba optiliste efektide loomise juures 1960. aastate lõpul.

Koola poolsaare kivilabürinte uuris 1842. aastal esimesena Karl Ernst von Baer, hiljem Karl von Löwis of Menar. Esimene avaldas oma uurimustöö tulemused Peterburi Teaduste Akadeemia bülletäänis, kus kirjeldas ka Eestis Soome lahes Viri pisisaarel leiduvat labürinti (Kaplinski 1979: 34). Tema uurimuste materjalidele on toetunud ka Kaljo Põllu, visualiseerides neid oma piltides. Kunstnikku huvitab aga eriti küsimus, mil viisil selline täpne ja keeruline sümbol on püsinud muutumatult ja levinud üle nii laialdase ala. Üheks võtmeteguriks võib olla selle ülestähendamine, mistõttu neid saab korduvalt kasutada (Põllu 1996a: 15). Sealjuures on K. Põllu lisanud ka klassikalise seitsmekäigulise labürindi joonistamise viisi.

Tema sõnul on sealjuures ka labürinti läbi ajaloo püütud mõtestada kui Maaema kehaosa, jumaliku neitsilikkuse keskpunkti, mille keskmesse jõudmiseks tuleb sooritada rännak tema üska, mis on omamoodi tagasiminek sünnieelsesse seisundisse, regressus ad uterum. Rituaalne rünnak sinna ja tagasi sümboliseerib aga elu lõputu ringlemise ehk surematuse ideed (Põllu 1996a: 15).

Muinasskandinaavia saagades seostati labürinti teadaolevalt selle all asuva koopaga, Maaema elupaigaga, ettekujutusega inimese sünnist alguse saava müstilise teekonnaga surmani ja sealt tagasitulekuga uuestisündimise teel (Rahi \& Viik 1978: 315). Psühholoogiliselt tõlgendades kujutab labürint pürgimist keskmesse ja on võrreldav india usundeis kasutatava kindlate reeglite järgi joonistatud mediteerimispildi, mandalaga.

Labürinte on seostatud ka päikese nähtava teekonnaga taevavõlvil ja imetajate loote pildiga emakas (Kaplinski 1979: 35). Viimasega on seotud ka hopi indiaanlaste (Põhja-Ameerika, Arizona) labürintornamendid (Feest 1992: 34).

Kristlus võttis labürindi ürgse sisu üle ning lõi selle pinnalaotustele võrdkujulise usutalitusliku palverännaku traditsiooni Pühale Maale, Jeruusalemma ja tagasi. Tänapäeval on Eesti kivilabürintide kohta teateid veel Hiiumaalt Reigi rannast, Aksi ja Aegna saarelt. Et Kaljo Põllu ise on päritolult hiidlane, oli ta Reigi ranna labürintidest hästi teadlik, lähtudes nendest kujunditest mitmes 1970. aastatel valminud graafikasarjas. 


\section{Mõtestamas legende kodalastest}

Kunstiteadlane Voldemar Erm on Kaljo Põllut teravmeelselt ja paikapidavalt iseloomustanud juba 1976. aastal seoses "Kodalaste" ekspostsitsiooniga Eesti Kunstimuuseumis järgmiselt:

Kaljo Pôllu pole oma must-valgel põllul töötades mitte pinnalibistaja, vaid sügavkünnimeister (Erm 1976: 7).

"Kodalaste" sarja luues on K. Põllu kasutanud ühelt poolt raskepärast, stiliseeritud, muistseilt kaljujoonistelt pärinevat üldist vormikõnet, teiselt poolt aga mähkinud oma kujundid mütoloogilistesse narratiividesse, rakendades metsotinto pehmeid üleminekuid ja varjundeid.

1964. aastal käis Kaljo Põllu üliõpilastega Koola poolsaarel ja 1965. aastal Taga-Kaukaasias. Nii üks kui teine käik pakkus loominguks ohtrat ainet, kuid see kõik polnud tema enda sõnul ikka veel see, mida otsis. 1966. aastal sõitis Tartu üliõpilaskond Jaan Eilarti juhtimisel ekskursioonile Siberisse. Sellel reisil nähtu põhjal esitaski K. Põllu oma loomingu kolm põhjapanevat küsimust: kust tuleme, kes oleme, kuhu läheme? Kunstniku väitel peaks just see olema "Kodalaste" kandev idee (Põllu 2002). Ometi kulus seitse aastat, enne kui valmis esimene leht "Uni", millest kasvas välja sari. ${ }^{5}$

1967. aastal reisis ta K. Põllu koos Veljo Tormise ja Jaan Eilartiga Kura poolsaare liivlaste juurde, mis oli kunstnikule samuti inspireeriv ja määrava tähtsusega hõimurahvaste loomingu tõlgendamisel.

Peatselt selle järel valmis leht "Kahekesi", millel autor tabas õige tüübi. Sealjuures andsid kõige enam inspiratsiooni handid ja mansid, kelle juures on K. Põllu väitel enim säilinud ugrilaste ürgseid jooni. Iseloomulik on ka "Kodalaste" valmimise pikk protsess, kus olulise osa moodustasid just tüübiotsingud. Viimane, 25. leht mahukast sarjast valmis 1975 . aastal.

Ka see pole juhus, et K. Põllu esimene graafiline soome-ugri temaatikast lähtuv sari "Kodalased" ilmus samal aastal Lennart Meri raamatuga Hõbevalge. Kaljo Põllu ise põhjendab seda aja nõudmisega, sest 1968. aasta traagilised noorterahutused Prahas jätsid mulje, et kommunism on igavene ja eesti rahvuse täisväärtusliku püsimine nii keeles kui ka kirjas muutus kriitiliseks. Selliste meeleolude vastu olidki mõeldud Hõbevalge ja "Kodalased". Arvatavasti peitub selles usk kultuuri arengu paratamatusse ja selle arengu sõltumatusse ühest või teisest konkreetsest inimesest. 


\section{Riin Kübarsepp}

Rahvusliku filosoofia ja ürgse alge, mis peitub "Kodalaste" seerias, on K. Põllu leidnud paljuski ka A. H. Tammsaare kirjanduslikust pärandist. Samas kõneleb ta avameelselt, et on oma tööde ainese poolest tõepoolest astunud Kristjan Raua ja Nikolai Triigi jälgedes ja kõndinud ühel rajal Veljo Tormise ja Lennart Meriga.

Akadeemik Paul Ariste tõlgendas Kaljo Põllu huvi soome-ugri alglätete vastu nende rahvaste elujõuga, kes karmides tingimustes, kus tsiviliseeritud kultuurrahvad oleksid hävinud, suutsid olelusvõitlusele vastu seista (Ariste 1979: 3).

Mark Soosaar võrdleb Kaljo Põllut Kalevipojaga, kes Lennukiga maailma äärele lähenedes soovis mitte ainult näha kaugeid maid ja rahvaid, vaid õppida paremini tundma iseennast ja otsida üles paik, kust tema rahvas esimese seemne sai. M. Soosaare sõnul pole nende tööde sisu võimalik literaaditsedes kunstipublikule dekonstrueerida, sest põhjamaa rahva karge maailma peamisi seadusi on paljutähenduslik ja pingestatud vaikimine (Soosaar 1979: 2).

Bioloog Jaan Eilart peab üheks peamiseks faktoriks tema maailmavaatelises arengus ikkagi 1966. aastal Tartu ülikooli korraldatud bussiretke Siberisse, kus liiguti piki Volga-äärseid traditsioonilist kultuuri viljelevaid külasid, läbiti Kaasan, kontrastiks Baškiiria Bugulma öises gaasiloiduses naftaväljad - seal jäid silma konfliktid tsivilisatsioonide tasandil ülimusliku tööstuse ning põlisrahvaste kombestike ja väärtuste vahel. Samal uurimisreisil külastati ka eesti nimedega hauakohti Uuralites ning maride ja mordvalaste maagilisi muinasvälju. J. Eilarti väitel sundisid arvatavasti just sellised elamused graafilise sarja "Kodalased" abil arutama nende rahvaste pühade kujundite ja uskumuste üle (Eilart 1974).

"Kodalaste" puhul võib esile tuua erinevust tolleaegse eesti graafika üldsuundumustest ning püüdu äärmise lihtsuse ja lakoonilisuse poole, mida iseloomustavad rahvakunsti rustikaalsus ja tingmärgid.

"Kodalastes" ja "Kaliväes" elustuvad paljud soomeugrilaste ühisvaramusse kuulunud, nüüdseks üsna unustatud ja vaevu rekonstrueeritavad mõisted, nagu maailmamuna, ilmatala, maaema, hingelinnud, päikesevene, taevapõdrad, samuti loomapeadega dekoreeritud muistsete manatarkade riitused. Üks põhjusi, miks Kaljo Põllu pole oma "Kodalaste" seeriaga kriitikute hammaste vahele jäänud, on arvatavasti tegelemine nn tagalaga, toetudes seni põhjalikult uurimata mütoloogilisele ainele ning varjates tagasitõmbunult ja rafineeritud viisil kunstnikele omast tunnustusvajadust. 
Heitnud 1970. aastate algusest kõrvale soovi võidelda kohaliku kunstimaastiku avangardis, eelistas ta pigem stabiilset edasiliikumist kindlates väljendusvahendistes, sisus ja vormis. Ta on oma teostes alati balansseerinud igavese ja ajutise vahekordadel, murdes sealjuures pead igavese liikumise ja igitardumise üle.

\section{Kristjanraualik ja kaljopõllulik}

1975. aastal määrati Kaljo Põllule Kristjan Raua nimeline vabariiklik kunsti aastapreemia metsotintotehnikas loodud graafilise sarja "Kodalased" eest. Kunstiteadlane Mart-Ivo Eller on väitnud, et Kultuuriministeeriumi ja Kunstnike Liidu juhatuse presiidiumi otsuses rõhutati preemia määramisel graafilise sarja ulatuslikkust, etnograafilise temaatika käsitluse kunstilist üldistusjõudu ja tehnilise meisterlikkuse abil saavutatud emotsionaalset väljenduslikkust.

Kaljo Põllu seost Kristjan Rauaga on M. Eller tõlgendanud üldistatult ja lakooniliselt: mõlemad kunstnikud on püüdnud süveneda oma rahva kaugesse minevikku ning osanud muistsete aegade mõttemaailmast leida oma kaasajale olulist järjekestvust. Mõlemad graafikud on suutnud avastada muistsetest saagadest midagi uut, mida just nende loomingu sünniaegadel oli vaja oma kaasaegsetele vahendada.

Lisaks kõigele eelnevale seisneb Kaljo Põllu tööde eripära ka kasutatud tehnikas. Metsotinto võimaldab kunstitegijale rohkem maalilisust kui teised (graafilised) tehnikad. Teinekord isegi rohkem kui tõeline maal, sest metsotintos on võimalikud üleminekud sumedateks pool-, veerand- ja koguni kuueteistkümnendiktoonideks.

Maastikulembeseid kunstnikke on eesti kunstiajaloo annaalidesse kantud tosinate kaupa. Kaljo Põllu juures väärib toonitamist, et ta on maastiku vallas suutnud leida oma vaatenurga, esitades looduselõike nende ürgsel, inimtegevusest puudutamata kujul. Looduse üksikmotiivide reaalsus omandab Jüri Kuusekmaa sõnul pilditervikuteks liidetuna mitte kirjeldava, vaid kokkuvõtliku, sümboolse mõjujõu. Sealjuures pole J. Kuuskemaa esimene kunstiajaloolane, kes leiab, et hoiakutelt ja tundetoonilt, mis on eepiline, kalkuse ja romantiline härdusnõretuseta, sunnivad Kaljo Põllu maastikulised metsotintod meenutama Kristjan Raua söemaale 


\section{Riin Kübarsepp}

Pedaspea-Riguldi perioodist ja Kalevipoja-lehtede lakoonilisi, ent jõulisi maastikulisi taustu (Kuuskemaa 1979: 3).

Seoses 1973. aastal alustatud "Kodalaste" sarjaga on K. Põllu eesti kunstis pärast pikka pausi Vive Tolli järel üks Kristjan Raua rajatud suuna jätkaja, kelle juured ulatuvad rahvapärimuste ja rahvakunsti veel viljastava lademeni.

Kui Kristjan Raud pöördus meie päevini rahvasuus püsinud eesti muistendite poole, siis K. Põllu ammutas ainet Lapimaalt Uuraliteni soome-ugri hõimude vaimsest pärandist. Sealjuures polnud "Kodalaste" loomine talle mitte üksnes esteetiliste, vaid ka eetiliste probleemide mõtestamiseks ja väljendamiseks.

Juba graafiliste lehtede motiivid, mis osutavad lähemale tutvusele põhjala rahvaste iidsete kunstitraditsioonide ja materiaalse kultuuriga, eristavad tema loomingut K. Rauale omasest lapidaarsest ja tahumatust kujundikeelest.

Pärast 1960. aastate keskel läbitud retki Koola poolsaarele valmis aastatel 1976-1977 kuivnõelatehnikas sari "Põhjala", mis käsitleb laplaste elu. Oma teadmisi ja muljeid sealsest elu-olust ei kandnud K. Põllu kunsti üle mehaaniliselt, sest vastupidiselt $\mathrm{K}$. Rauale polnud tema eesmärgiks illustreerida ajalugu ega folkloristikat.

Olustikulised stseenid omandavad sarjas sümboli tähendusrikkuse ja sisemise monumentaalsuse. Mai Levini sõnul aitab sellele kaasa stiil, milles napisõnaline realism ja lihtsustatav vormikäsitlus liitub nägemusliku ruumimõjuga ning metsotinto salapärase sumedusega. Teinekord meenutavad kodalaste kohmakad, jässakad figuurid põhjarahvaste kunsti, mis oma näiva primitiivsuse juures on tulvil elulist ilmekust ja ehtsat kunstilist tunnetust. K. Põllu püüab mineviku kaudu öelda seda, mis paistab talle tuleviku seisukohalt oluline (Levin 1979: 2).

1996. aastal sai Kristjan Raua majamuuseumis teoks K. Põllu värviliste graafiliste lehtede näitus pealkirjaga "Kosmogooniline teema Kaljo Põllu loomingus". Kõnealune väljapanek oli kui kvintessents kunstniku loomingut läbinud kosmogoonilisest temaatikast. Kosmogoonilises taustsüsteemis võimendub rahvuslik pärimus, sulandudes lõputusse kõiksuse kulgemisse. Sealjuures on kosmogoonia üheks oluliseks märksõnaks, millega K. Põllu diferentseerub kardinaalselt Kristjan Raua loomingust. 1985. aastal pälvis ta programmilise metsotintoseeria "Kalivägi" eest taas Kristjan Raua preemia. 
Mõisted kristjanraualik ja kaljopõllulik on aastatega kindlalt juurdunud eesti kunstiajalukku. Oma artiklis "Taevaste ja maiste jõudude kohtumine" on Renate Riibak nimetanud Kaljo Põllut kõige kristjanraualikumaks kunstnikuks, põhjendades seda rahvusromantilise atmosfääri ja huviga legendaarse pärimuslikkuse vastu (Riibak 1996: 11). Rahvusromantiline atmosfäär on aga petlik, liiga pealiskaudse vaatluse tulemus.

Luues ürgse maailmamüüdi teisendusi, seletab K. Põllu selle kaudu ka kunsti uusimaid ilminguid (op-, pop- ja kineetiline kunst jm).

Sümbolite külluse tõttu muutuvad erinevad kujundid K. Põllu töödes piktogrammideks ilmamärkide, taevaste ja maiste jõudude, nähtava ja nähtamatu maailmaga. Juba ühel metsotintolehel kujutatud "Maailmapuu" on samaaegselt nii ilmasammas kui ka elutarkuse sümbol. ${ }^{6}$

Kõiksuse mitmemõõtmelisus, inimliku ja jumaliku ühtsus teispoolse ja reaalse üheaegne kohalolek moodustavad K. Põllu piltidel justkui loomuliku olemise vormi. Kaljopõllulik poeetiline nägemus on leidnud maalilise lahenduse eelkõige metsotintotehnikale omase värvikäsitluse tõttu (Riibak 1996: 11).

Mõiste kristjanraualik on märksa kergemini defineeritav kui kaljopõllulik. Kaljopõlluliku sünonüümiks osutuvad "Kodalased", mis on sügava soome-ugri orientatsiooni, arhailise sisu ja sümbolite tõttu märksa mitmetasandilisem kui näiteks Kristjan Raua eesti rahvuseeposele tuginev teos "Kalevipoeg laudu kandmas".

\section{Kaljo Põllu Põhjamaade kultuuri mõjusfääris}

Olulist osa Kaljo Põllu loometöö kujunemisel etendasid suhted Soomega ja seda just 1960. aastate keskel, mil läbikäimine ja infovahetus Läänega oli kunsti-ja kultuuriringkondades üldjuhul välistatud. Oma osa oli selles ka reisilaevaliikluse taasavamisel Tallinna ja Helsingi vahel.

Juba 1960. aastate teisel poolel oli K. Põllu kursis soome moodsa kunsti rahvusvaheliselt tuntud esindajate loominguga, tuues oma perioodiliselt ilmuvates artiklites soome kunstist esile eriti Gösta Diehlit, kes asutas 1950. aastail rühmituse Prisma, millesse kuulusid tuntud meistritena ka Yngve Bäck, Ragnar Ekelund, Unto Pusa ja Sam Vanni. Kollaažitehnika kasutajatest märgib K. Põllu ära Igor Erikssoni, Eino Ahoneni, puhta popkunstiga tor- 


\section{Riin Kübarsepp}

kasid talle silma Paul Osipow, Leo Lindsten ja Leo Leskinen (Põllu 1967: 3).

Kui K. Põllu op- ja popkunstiteemalistel töödel on vaid lokaalne, Eestile oluline tähendus ja nende sõnum on märkimisväärne üksnes kohalikus kontekstis, siis graafikaga saavutas kunstnik ka globaalse tuntuse. Tänu sellele õnnestus tal ka pääseda füüsiliselt väljapoole Eesti NSV piire, levitamaks ideed põliseestlusest ja soome-ugrilusest ja müstifitseeritud maailmanägemusest. K. Põllu Euroopa-näitused said teoks peamiselt tänu erinevate maade Soome Instituutidele, mis tema töid ühest riigist teise vahendasid.

Norra keeleteadlane ja estofiili Turid Farbregdi väitel etendasid K. Põllu tööde sattumisel Norrasse suurt rolli Eva Lille kultuurireisid Eestisse. Tänu Eva Lillele jõudis 1980. aastal ka "Kodalaste" sari esimest korda Soome ja Norrasse. Samas oli oluline ka kunstniku intensiivne kirjavahetus rootsieestlase Harry Oltiga, kelle vahendusel korraldati kunstniku tööde rändnäitused nii Rootsis kui ka Norras. T. Farbregdi väitel imponeerisid "Kodalased" oma tahumatu stiili ja mütoloogilise sisu poolest eriti Edela-Norra saamidele. Nõnda oli K. Põllu näol Norras tegu justkui misjonäriga, kes tuli nn oma usku kuulutama, puudutades oma töödes kaudselt ka teravaid probleeme kohalike saamide enesemääratlemispüüdes (Farbregd 2001).

Kaljo Põllule omane poetiseeriv laad avaldub eriti selgelt 1980. aastate alguse metsotintosarjades, mis oma tahumatu sünguse ja kargusega imponeerivad just põhjamaisele kunstipublikule. ${ }^{7}$

Kõige ulatuslikumaks esinemiseks Põhjamaades võib aga pidada 1986. aastal korraldatud väljapanekut Rootsis Södertälje Kunstihallis, kus eksponeeriti 16 lehte "Kodalaste" ja 25 lehte "Kaliväe" sarjast, lisaks veel 12 vabamotiivi tõmmist peamiselt "Eesti maastike" hulgast. Näitus sai teoks Rootsis asuva Balti Instituudi ja $V{ }^{2} S_{S A}^{8}$ ühingu ühisettevõtmisena. Sellele lisandus omamoodi teatraliseeritud interdistsiplinaarne (muusikaline) pildiprogramm, mis tähendas, et kuue projektoriga näidati kolmel liidetud ekraanil ligi 200 fotot Kaljo Põllu graafilistest lehtedest ja nende detailidest, saateks Jaan Kaplinski rootsi keelde tõlgitud tekst ja Eduard Tubina nn "Virmaliste sonaat". See oli rändnäitus, mis liikus edasi Göteborgi, seejärel Umeåsse ja Örebrosse. Ilmus ka 30-leheküljeline kataloog "Tuule ja vee lapsed" Jaan Kaplinski tekstiga (Kaplinski 1986).

Soome teaduskeskuse Heureka rändnäituse "The Kalevala People" koosseisus oli 1992. aasta kevadel USAs Seattle'is Nordic Heritage 
Museum'is väljas valik töid metsotintosarjadest "Kodalased", "Kalivägi", "Eesti maastikud" ning "Taevas ja maa".

K. Põllu korraldatud soome-ugri ekspeditsioonide tutvustamiseks läänemaailmas on suurt abi osutanud Soome keeleteadlased professor Pertti Virtaranta ja eesti keele lektor Eeva Niinivaara, nagu ka keeleuurijad Kaarina Pöykkö ja Kalevi Pöykkö Jyväskylä Ülikoolist. Mõlemas ülikoolis, samuti Helsingi Tarbekunstimuuseumis ja Helsingi Kõrgema Kunsttööstuskooli soovil ka Lõuna-Karjala Kunstikeskuses Savitaipalel on K. Põllu korraldanud mitu ekspeditsioonimaterjalide põhjal valminud kunstiloomingu näitust. Lisada võib veel Helsingi Tuglase Seltsilt ja Oulu Ülikoolist saadud abi ning Karjala kaljujooniste koopiate väljapanekud Rootsis ja Norras (Põllu 1999: 32).

Siinkohal on paikapidavad endise Eesti Soome Instituudi juhi Juhani Salokanneli mõtisklused Eesti ja Soome kultuurisidemetest:

Möödunud sajandi algul kippusid kunstiuurijad kirjanike ja heliloojate ja kunstnike teostes nägema õige palju "mõjusid". Hilisemal ajal pole kultuuri- ja kunstimaastik nii selgesti tajutavalt jagunenud keskusteks ja perifeeriaks (Salokannel 2002: 251).

J. Salokannel toob võrdluseks graafik Herald Eelma, kelle "Kalevala" illustratsioonides on lähedane suhe Soomega selge ja tulemus huvipakkuv. Selline seos viib tänapäeva eesti kunstniku ateljeest soome rahvaluulesse, mitte niivõrd oma aja soome graafikasse. Mõjutused ilmnevad siin aines, mitte aga kunstivahendites ja teoste teostuses. Seega kutsub J. Salokannel mõjusid otsima mitte teoste ainevalikust, vaid teoste vormist (Salokannel 2002). Paljudele 1950. aastate lõpu sulaajal elanud kunstnikele avas just Soome tee Stalini aja eraldatusest maailma uue kunsti juurde.

Soomalane Heikki Kastemaa on kirjutanud, et Kaljo Põllu tööd on väga kristlikud, millest võib järeldada, et need on loodud põhimõttel: alguses oli sõna, seejärel pilt. J. Salokannel peab aga vanema põlvkonna eesti kunstnike eeliseks seda, et nõukogude aeg andis paljudele kunstiinimestele kui mitte just märtri, siis vähemalt teisitimõtleja kogemusi: sellist julgust ja usku iseendasse, mida vaba Lääne kunstnik lihtsalt ei saa mitte kuskil õppida. Teisitimõtleja ja muganeja põimusid nõukogudeaegse kunstiinimese loomuses keerukal viisil (Salokannel 2002: 253).

Eesti kunstnikule omase integratsiooni, intellektuaalsuse ja iseteadvusega võib iseloomustada ka Kaljo Põllu tegevust. See on vaimne 


\section{Riin Kübarsepp}

sõltumatus, kõrge eneseteadvus ja juurdlev vaim. Tema tööd kindlustavad samaaegselt rahvuse identiteeti ja hoiavad alal selle mälu.

\section{Kokkuvõte}

Käesoleva kirjutise alguses püstitati küsimus murrangutest ja murdepunktidest Kaljo Põllu loomingus, kus 1960. aastate lõpu Eesti kunsti novaatorlikust avangardistist sai pühendunud fennougrist ja soome-ugri mütoloogia visualiseerija. Saamaks selgemat pilti 1960. aastate lõpu sulaaja kunsti-ja kultuuriilmingutest ning poliitilisest olukorrast oli esimeses osas Jaak Kangilaski teooriatele toetudes moodustatud teatav eellugu kui taustsüsteem, milles orienteeruda.

Ajastukontseptsiooni seisukohalt osutusid olulisteks ja pöördelisteks ka Kaljo Põllule endale just 1968. aasta sündmused nii Euroopas kui ka Ameerikas, mida on rõhutatud ka antud kirjutise mitmes osas.

Ometi on ülevaade K. Põllu loomingu erinevatest aspektidest pigem esseistlik. Selle eesmärk on pakkuda erinevaid tööde tõlgendamise mudeleid ja avanguid. Samas on puudutatud erinevaid märksõ$\mathrm{nu}$, nagu nativism ja globaliseerumine, millega suhestumine on eeltingimuseks käsitletavast teemast adekvaatsema pildi saamisel.

Kaljo Põllu oli Visarite kunstirühmituse asutaja 1966. aastal ja sealjuures ka nende tegevuse lõpetaja 1972. aastal. Seega võib tema loomingu radikaalse pöörde soome-ugri ainevaldkonda dateerida ka Visarite tegevuse lõpetamisega.

Kunstnik suhtles aga juba Visarite perioodil aktiivselt Paul Ariste, Jaan Eilarti ja Jaan Kaplinskiga, kes seega juba siis suunasid oma fennougristikat tutvustavate kirjutiste abil kaudselt kunstniku loomingulist käekäiku. Soome-ugri mõttemaailma analüüs antud kirjutises on seetõttu vajalik K. Põllu soome-ugri aineliste teoste mõistmiseks ja tajumiseks.

Paljude kunstnike nn loomingulise ümbersünni põhjustena võib esile tuua sulaaja lõppu, raudse eesriide jäigastumist ja ühiskondliku stagnatsiooni kulmineerumist. Iseloomustabju aastaid 1976-1986 avangardismi ideoloogia nõrgenemine, kus tugevnes rahvuslik-konservatiivne mõtteviis, mis sidus end estetistliku traditsiooniga. Kaljo Põllu, nagu teiste juhtivate avangardistide puhul (silmas on peetud nt Tõnis Vinti), tähendas 1970. aastate stagnatsioonis ürgse mütoloogia poole pöördumine pääseteed vaimse sõltumatuse säilita- 


\section{Riin Kübarsepp}

misel. Teisitimõtleja ja muganeja põimusid nõukogudeaegse kunstniku loomuses keerukal viisil. Kaljo Põllu tööde puhul on aga oluline just moodsa kunsti ja rahvuslikest juurtest lähtuva kunsti suhe.

\section{Kommentaarid}

${ }^{1}$ Sealjuures arutleb Leonardo Mercado, nagu Oskar Looritski, pikalt hingekontseptsiooni üle, analüüsib eri sugulaskeelte termineid. L. Mercado kirjutab, et antropoloogia ja keeleteaduse andmed sisaldavad implitsiitset filosoofiat. Nii võiks eesti või mõne muu soome-ugri rahva filosoof (antropoloog) teha sammu O. Looritsast ja Uku Masingust edasi ning püüda soome-ugri keeleteaduse ja antropoloogia andmeid filosoofiliselt tõlgendada ja korraldada. Filosoofilise antropoloogia, kitsamalt "meelefilosoofia" või "teadvuse filosoofia" (philosophy of mind) vallas, mis ei pääse tegelemast hinge, vaimu, meele ja teadvuse ning keha, elu ja surma mõistetega, võiks leida palju inspiratsiooni O. Looritsa, Ivar Paulsoni ja teiste töödest (Kaplinski 2002: 232).

${ }^{2}$ A. H. Tammsaarest on jäänud järele raamat "Hiina ja hiinlased", Oskar Loorits toob soome-ugri ja hiina paralleele ohtralt oma viimastes paguluses ilmunud töödes (Kaplinski 2000: 9).

${ }^{3}$ Siingi liialdab O. Loorits selgelt, kuid mõndagi tema väidet tasub tõsiselt võtta On ju nüüdki eesti keel tüpoloogiliselt lähemal näiteks tamili või mongoli keelele kui prantsuse ja hispaania keelele. Ühisjooni on ilmselt ka suhtlemiskultuuris, sest eestlasel on mongoliga suhelda kergem kui itaallasega. Nõnda on ka eestlaste suhtumine vaikusse ja üksindusse ning metsa lähemal tunguusi kui prantslase suhtumisele (Kaplinski 2000).

${ }^{4}$ Vt Kaljo Põllu kirjutist labürintidest ajalehes Postimees 3. jaanuaril 1996 (Põllu 1996a).

${ }^{5}$ Kunstiteadlase Voldemar Ermi sõnul sünnitas soome-ugri kodalaste primitiivseis, raskeis, tingimustes kulgenud elu Kaljo Põllus uskumusi ja tavasid, mis läbini olid seotud loodusega, inimeste igapäevase elukeskkonnaga ja võitlusega elu kestmise eest. Sisuliselt hõlmab sari kujutelmi kodalaste igapäevase elu ja töö ringist, nagu "Jaht" (tagaplaanil kuuskedeks maskeerunud jahimeestega), "Leib" (leiva pärast muretseva pereemaga tare interjööris) "Mehed" ja "Humal", mis kujutab šamaani trummi saatel tantsivat ja laulvat meesteringi humalajoobes (Erm 1976: 7).

${ }^{6}$ Ürgsete uskumuste kohaselt pidi inimene saama jõudu, juhatust ja tervist nn taevase tarkuse läbi, õnnestuma täielikult nii ka oma maapealses olemises, kui ta vaid tajub maise ja taevase ühtsust (Riibak 1996: 11).

${ }^{7}$ 1995. aasta märtsis eksponeeriti Pariisis Soome Instituudis (Rue des Ecoles 60) Kaljo Põllu loomingut, väljas oli valik tema metsotintosarja- 


\section{Riin Kübarsepp}

dest "Kodalased”, "Kalivägi”, "Eesti maastikud” ning “Taevas ja maa”. Prantsuskeelsel kutsekaardil, millele lisandus näitust tutvustav voldik, oli muu hulgas öeldud: "Kaljo Põllule on iseloomulik panna tähele algupära - meie ehtsust, meie muutumist. Tema graafika kujutab loodust sageli idealiseeritult, suhtes inimesega, milles märkame igavest mängu valguse ja varju, päeva ja öö, nähtava ja maa-aluse maailma, headuse ja kurja vahel. Kaljo Põllu graafikas kohtame seesmiselt jõulist nägemust ning otsekohesust - alates inimese kujutamisest, alates mõttest, milles tööd toetuvad ühele arusaamale, müüdile. Ta on natuke šamaan: sellest sünnivad tema pildid.” Seega oli ja on Kaljo Põllu teoste ainese omanäolisusele ja müütilisusele raske tõmmata paralleele nii kohaliku kui ka väliskunstiga, kus oleks sedavõrd otse puudutatud soome-ugrilikku kosmogooniateemat.

${ }^{8}$ Nõukogude Eestis tegutsenud Väliseestlastega Kultuurisidemete Arendamise Ühing, mis loodi Hruštšovi sula päevil analoogselt Läti ja Leedu sõsarorganisatsioonidega, esialgne nimetus oli Väliseestlastega Sidemete Arendamise Komitee (Jürjo 1996) (toimetaja märkus).

\section{Kirjandus}

Ariste, Paul 1979. Kodalased. Noorte Hääl, 8. september.

Asu-Õunas, Ene 1998. "Kirgastumine" - iseenda olemise kulg. Postimees, 27. jaanuar.

Eilart, Jaan 1974. Veri on see, mis rähnipoja... Noorte Hääl, 22. juuni.

Epner, Luule \& Annus, Epp \& Järv, Ants \& Olesk, Sirje \& Süvalep, Ele \& Velsker, Mart 2001. Eesti kirjanduslugu. Tallinn: Koolibri.

Erm, Voldemar 1976. Kaljo Põllu "Kodalased”. Kodumaa, 2. juuni.

Farbregd, Turid 2001. Riin Kübarsepa vestlus Turid Farbregdiga. 13. mai.

Feest, Christian. F. 1992. The Native Arts of North America. London: Thames and Hudson.

Helme, Sirje 1997. Kunstirühmitus Visarid. Põllu, Kaljo (koost \& toim). Kunstirühmitus "Visarid": Tartu, 1967-1972: Näituse kataloog: Tallinna Kunstihoone Galerii, 27. novembrist-14. detsembrini 1997 = The "Visarid" artist's group: Tartu, 1967-1972: Exhibition catalogue: Gallery of the Tallinn Art Hall, November 27 - December 14, 1997. Tallinn: [Tallinna Kunstihoone], lk 4-11.

Helme, Sirje 2000. Mitteametlik kunst: Vastupanuvormid Eesti kunstis. Näripea, Eva \& Sarapik, Virve (toim). Kunstiteaduslikke uurimusi= Studies on art and architecture $=$ Studien für Kunstwissenschaft 10. Tallinn: Eesti Kunstiteadlaste Ühing, lk 253-269. 


\section{Riin Kübarsepp}

Hennoste, Tiit 1996a. Hüpped modernismi poole: Eesti 20. sajandi kirjandus euroopa modernismi taustal. Vikerkaar 3, lk 69-76.

Hennoste, Tiit 1996b. Hüpe modernismi poole: Eesti 20. sajandi kirjandus euroopa modernismi taustal. Vikerkaar 4, lk 86-93.

Juske, Ants 1997. Visarid ja eesti kunst kolmkümmend aastat hiljem. Sirp, 12. detsember.

Jürjo, Indrek 1996. Pagulus Nõugkode Eestis: Vaateid KGB, EKP ja VEKSA arhiivi dokumentide põhjal. Tallinn: Umara.

Kangilaski, Jaak 1997. Paradigma muutus 1970-ndate aastate Lääne kunstis ja selle kajastus Eesti kunstielus. Rujaline roostevaba maailm: Näitus Tartu Kunstimuuseumi Kivisilla Pildigaleriis, 28.II-27.IV 1997, seminar “1970-ndate aastate eesti kunst". Tartu: Tartu Kunstimuuseum, lk 3-8.

Kangilaski, Jaak 2001. 1970. aastate Lääne kunstist. Kangilaski, Jaak. Kunstist, Eestist ja eesti kunstist. Eesti mõttelugu 34. Tartu: Ilmamaa, lk 84-98.

Kaplinski, Jaak 1979. Ikka labürintidest. Eesti Loodus 1, lk 33-35.

Kaplinski, Jaan 1986. Kaljo Põllu's art shown in Sweden. Homeland, 24. detsember.

Kaplinski, Jaan 2000. Kultuurifilosoof Loorits ja tema sõnum. Eesti Ekspress, 16 . november.

Kaplinski, Jaan 2002. Soome-ugri keeled ja filosoofia. Looming 2, lk 231253.

Kutšõran, Juri 2001. Udmurdi šamanismist. Kunst.ee 2, lk 94-96.

Kuuskemaa, Jüri 1979. Legende mõtestamas. Rahva Hääl, 22. mai.

Künnap, Ago 1996. Maakaart maskis: Taas uurali asjust. Akadeemia 10, lk 2019-2029.

Levin, Mai 1979. Pilk kunstniku maailma. Õhtuleht, 24. mai.

Põldmäe, Asta 1984. Kes me oleme... Sirp ja Vasar, 20. aprill.

Põllu, Kaljo 1967. Sugemeid Soome kunstielust. Edasi, 29. jaanuar.

Põllu, Kaljo 1971. Visarite manifest. Käsikiri. 23. august.

Põllu, Kaljo 1990. Kaks tähekaarti karjala kaljujoonistel. Horisont 8, lk 18-24.

Põllu, Kaljo 1995. Kolmanda aastatuhande kunst. Postimees, 7. aprill.

Põllu, Kaljo 1996a. Labürint. Postimees, 3. jaanuar.

Põllu, Kaljo 1996b. Võimatute maailmade loomine. Postimees, 17. detsember. 


\section{Riin Kübarsepp}

Põllu, Kaljo 1999. Eesti Kunstiakadeemia kakskümmend soome-ugri uurimisreisi = Estonian Academy of Arts twenty expeditions to the Finno-Ugrians. Tallinn: Olion.

Põllu, Kaljo 2002. Riin Kübarsepa vestlus Kaljo Põlluga 11. veebruaril.

Rahi, Märt \& Viik, Tõnu 1978. Kivilabürindid Eestis. Eesti Loodus 5, lk 315-317.

Rawson, Philip 1991. The Art of Tantra. London: Thames and Hudson.

Raudam, Toomas 1995. Punane joon. Kunst 1, lk 41-45.

Riibak, Renate 1996. Taevaste ja maiste jõudude kohtumine. Õhtuleht, 13. detsember.

Saar, Johannes 1998. Kaljo Põllu. Saar; Johannes (toim). Eesti kunstnikud = Artists of Estonia 1. Tallinn: Sorose Kaasaegse Kunsti Eesti Keskus.

Salokannel, Juhani 2002. Hingesild: Sillaehitaja mõtisklusi. Looming 2, lk 249-253.

Soosaar, Mark 1979. "Kodalased”. Noorte Hääl, 8. september.

Talvistu, Tiiu 1997. Põhisuundumusi 1970-ndate aastate eesti kunstis. Rujaline roostevaba maailm: Näitus Tartu Kunstimuuseumi Kivisilla Pildigaleriis, 28.II-27.IV 1997, seminar "1970-ndate aastate eesti kunst”. Tartu: Tartu Kunstimuuseum, lk 8-16.

Valk, Heinz 1997. Kunstielu partei kontrolli ja iseolemise vahel 1970ndatel aastatel. Rujaline roostevaba maailm: Näitus Tartu Kunstimuuseumi Kivisilla Pildigaleriis, 28.II-27.IV 1997, seminar "1970-ndate aastate eesti kunst”. Tartu: Tartu Kunstimuuseum, lk 19-20.

Wittgenstein, Ludwig 1996. Loogilis-filosoofiline traktaat = Tractatus logicophilosophicus. Kangilaski, Jaan sen. \& Palve, Veiko (tõlk). Avatud Eesti Raamat. [Tartu]: Ilmamaa.

Õunas, Ene 1984. Kaljo Põllu "Kalivägi”. Edasi, 15. detsember. 